\title{
Evolução metamórfica e termobarometria das rochas metamáficas/ metabásicas da região de Pontalina - GO
}

\author{
Guillermo Rafael Beltran Navarro', Antenor Zanardo², Fabiano Tomazini da \\ Conceição ${ }^{1}$ \& Luiz Sérgio Amarante Simões ${ }^{2}$
}

\begin{abstract}
Resumo Na região de Pontalina, o Arco Magmático de Goiás é constituído por ortognaisses, metassedimentos, metaultramáficas e metamáficas/metabásicas, geoquimicamente relacionadas a ambientes de arcos magmáticos. As associações minerais relacionadas ao auge metamórfico observadas na região são típicas da fácies anfibolito e foram geradas antes ou durante o estágio inicial do desenvolvimento da foliação principal ( $\mathrm{Sn}$ ). Cálculos termobarométricos mostram que as condições de $P$ e $T$, para as associações anfibólio + plagioclásio e plagioclásio + granada + anfibólio em rochas metamáficas/metabásicas, são da fácies anfibolito médio a superior, no campo de estabilidade da cianita. Os resultados indicam que o ápice metamórfico (M1) em fácies anfibolito médio a superior atingiu temperaturas pouco superiores a $700^{\circ} \mathrm{C}$, não ultrapassando $775^{\circ} \mathrm{C}$, em condições de média pressão ( $\sim 10 \mathrm{kbar})$. Os dados termobarométricos e petrográficos relacionados ao metamorfismo indicam um caminhamento $P$ - $T$ horário para as rochas da região.
\end{abstract}

Palavras-chave: Rochas Metamáficas/Metabásicas, Química mineral, Termobarometria.

\begin{abstract}
Metamorphic and thermobarometry evolution of the metamafics/metabasics rocks in Pontalina region, state of Goiás. At the Pontalina region, the Magmatic Arc of Goiás is constituted by orthogneisses, metasediments, metaultramafics and metamafic/metabasics, geochemically related to island arcs. Mineral assemblages related to metamorphic peak observed in the study area are typically of the amphibolite facies and were generated before or during the initial stage of the development of the main foliation $\left(\mathrm{S}_{\mathrm{n}}\right)$. Thermobarometric data show the $P$ and $T$ conditions for the amphibole + plagioclase and plagioclase + garnet + amphibole assemblages in the metamafic/metabasic rocks correspond to amphibolite facies (medium to upper grade), and plot in the kyanite stability field. The results indicate that the metamorphic peak (M1) in the amphibolite facies (medium up to upper grade) reached temperatures slightly higher than $700^{\circ} \mathrm{C}$, not exceeding $775^{\circ} \mathrm{C}$, under conditions of medium pressure $(\sim 10 \mathrm{kbar})$. Thermobarometric and petrographic data, related to the metamorphism, indicate a clockwise $P-T$ path for the surrounding rocks.
\end{abstract}

Keywords: Metamafics/Metabasics rocks, Mineral chemistry, Thermobarometry.

INTRODUÇÃO Rochas de composição básica (e/ou intermediária) são sensíveis a variações de temperatura e pressão, e comuns em cinturões orogênicos, podendo em alguns casos ser o tipo dominante, aspecto que motivou o estudo das associações minerais metamórficas presentes nestes litotipos (anfibolitos, anfibólios xistos e hornblenda gnaisses dioríticos), importantes para se determinar a evolução metamórfica de uma região. Associações minerais características desses litotipos metamorfisados na fácies anfibolito e epidoto anfibolito são marcadas pela presença de hornblenda + plagioclásio, hornblenda + epidoto + plagioclásio, além de granada, quartzo, ilmenita e titanita. Essas associações minerais, além de serem comuns em rochas metamáficas, possuem um amplo campo de estabilidade, desde a fácies anfibolito a fácies granulito e, por causa disso, diversos autores (por exemplo, Kohn \& Spear 1989, 1990, Blundy \& Holland 1990, Holland \& Blundy 1994) propuseram vários barômetros e termômetros baseados no par hornblenda + plagioclásio e hornblenda + plagioclásio + granada.

O objetivo principal deste artigo é apresentar os dados referentes às condições de metamorfismo às quais as rochas metamáficas/metabásicas, que ocorrem nos arredores dos municípios de Pontalina e Morrinhos (GO), foram submetidas, com base no estudo das associações minerais presentes nestas rochas.

A área de estudo situa-se na porção meridional da Faixa Brasília e, limita-se a lestes pelos metassedimentos da Zona Interna da Faixa Brasília (Grupo Araxá), a oeste por rochas supracrustais da Sequência Metavulcano-sedimentar Anicuns-Itaberaí e, a sul e sudoeste pelos sedimentos da Bacia do Paraná (Fig. 1A).

Na região de Pontalina, o Arco Magmático de Goiás é subdividido informalmente em duas unidades denominadas de Unidade Gnáissica e Unidade Metassedimentar. A Unidade Gnáissica é limitada a leste e a norte pelo Grupo Araxá e a oeste pela Unidade 

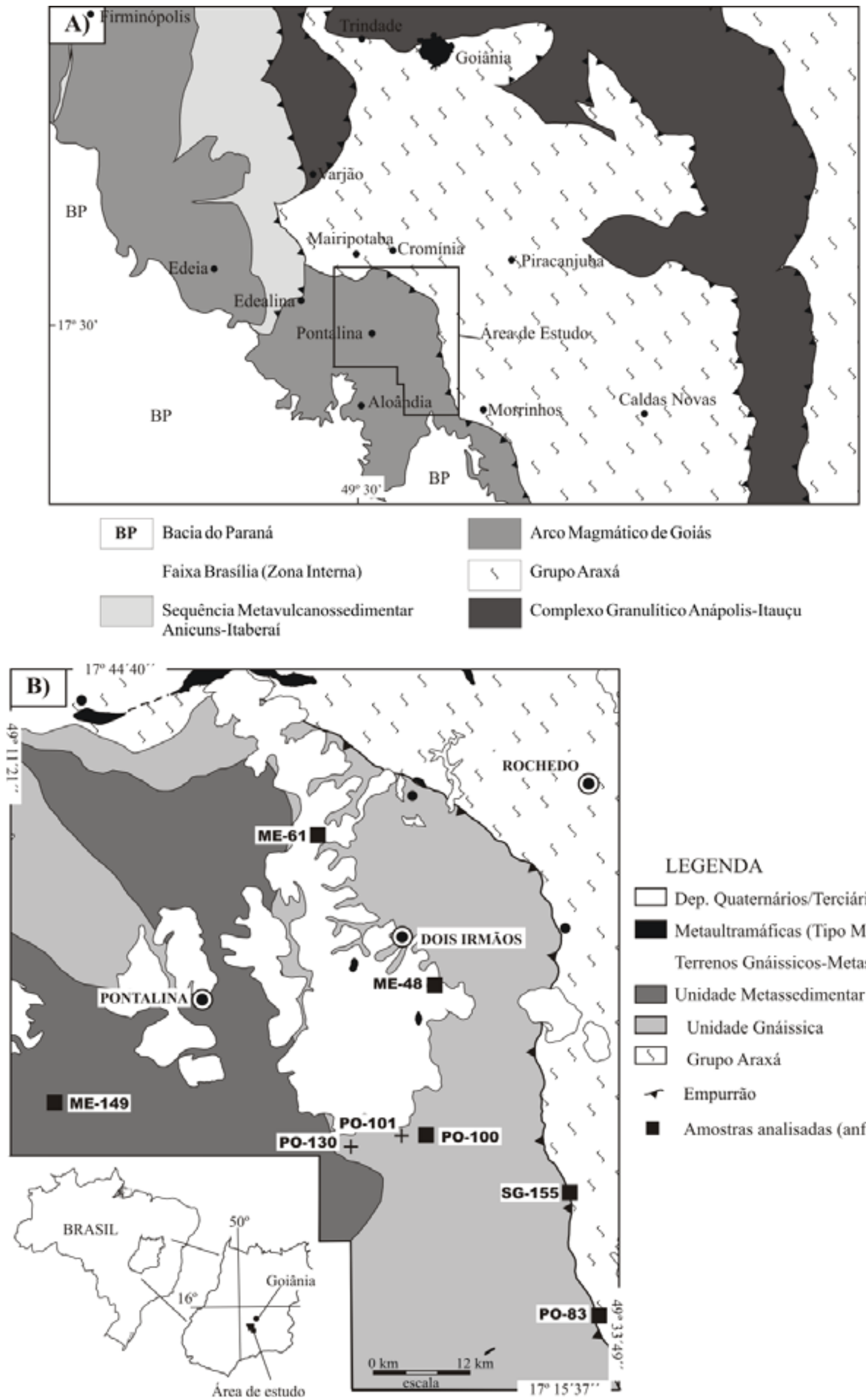

\section{LEGENDA}

Dep. Quaternários/Terciários

Metaultramáficas (Tipo Morro Feio)

Terrenos Gnáissicos-Metassedimentares

Unidade Metassedimentar

Unidade Gnáissica
Grupo Araxá

Empurrão

- Amostras analisadas (anfibolitos)

Figura 1 - (A) Mapa geológico esquemático regional mostrando a localização da área de estudo. (B) Mapa geológico esquemático da região de Pontalina mostrando a localização das amostras analisadas. 
Metassedimentar (Fig. 1B) e consiste em uma faixa de gnaisses variados que incluem muscovita gnaisse, biotita-muscovita gnaisse, hornblenda gnaisse, hornblenda-biotita gnaisse porfiroide ou não, geralmente quartzoso e rico em epidoto; com grau variado de milonitização. São frequentes intercalações de rochas metamáficas/metabásicas (anfibolitos e anfibólio xisto/fels) e sílico-aluminosas representadas principalmente por: muscovita xisto e muscovita-quartzo xisto. Quimicamente, os gnaisses desta unidade apresentam composição cálcica a cálcio alcalina, metaluminosa a peraluminosa, baixos teores em álcalis, enriquecimento em $\mathrm{Ba}, \mathrm{Sr}, \mathrm{K}, \mathrm{Rb}$ em relação a $\mathrm{Nb}, \mathrm{Y}, \mathrm{Zr}$ e ETR e anomalias negativas de $\mathrm{Ti}$ e $\mathrm{Nb}$, semelhantes à composição de magmas gerados em ambientes de arcos magmáticos (Navarro \& Zanardo 2007a).

Idades modelo $\mathrm{T}_{\mathrm{DM}}$ de gnaisses da Unidade Gnáissica variam entre 0,90 a $1,26 \mathrm{Ga}$, com composições isotópicas ${ }^{147} \mathrm{Sm} /{ }^{144} \mathrm{Nd}$ variando entre $0,1079-0,1487 \mathrm{e}$ ${ }^{143} \mathrm{Nd} /{ }^{144} \mathrm{Nd}$ variando entre $0,512173-0,512600$, semelhantes às de ortognaisses de outras regiões do Arco Magmático de Goiás, mostrando que estas são extensões do mesmo (Navarro \& Zanardo 2007a).

A Unidade Metassedimentar é constituída essencialmente por muscovita xisto, muscovita-quartzo xisto e quartzito, intercalados por muscovita gnaisse e biotita-muscovita gnaisse, geralmente com forte muscovitização e ricos em epidoto e rochas metamáficas/metabásicas. Os gnaisses desta unidade são orto ou paraderivados e apresentam composição predominantemente peraluminosa, afinidade cálcio-alcalina e norma predominantemente granítica. Exibem grande variação no conteúdo de elementos maiores e traços, com teores baixos a moderados de $\mathrm{Y}$ e $\mathrm{Nb}$ e alto de $\mathrm{Ba}$, $\mathrm{Sr}$ e $\mathrm{Rb}$, semelhante aos gnaisses da Unidade Gnáissica, que são relacionados a ambientes de arco de ilha, o que sugere ser parte do mesmo contexto geológico (Navarro \& Zanardo 2007b).

Rochas metaultramáficas (clorita xisto, talco xisto e serpentinito) ocorrem nas duas sequências, sendo a ocorrência mais importante a do Morro Dois Irmãos.

As rochas metamáficas/metabásicas (anfibolito, granada anfibolito, granada-anfibólio xisto e anfibólio xisto) ocorrem na forma de corpos lenticulares, de espessuras decimétricas a decamétricas e extensões métricas a hectométricas, orientados paralelamente ao bandamento das rochas encaixantes, tanto na Unidade Gnáissica como na Metassedimentar, sendo bem menos frequentes nesta última unidade. São de origem ortoderivada e, quimicamente, possuem natureza básica, predominando composições de basaltos subalcalinos e basaltos andesíticos e afinidade toleítica subalcalina a alcalina, com características geoquímicas semelhantes a basaltos oceânicos, principalmente do tipo E-MORB e de basaltos de arco (Navarro \& Zanardo 2006, Navarro et al. 2007). Dados isotópicos Sm-Nd de anfibolitos da região apresentam idades modelo $\mathrm{T}_{\mathrm{DM}}$ entre $1,0 \mathrm{a}$ 1,23 e composições isotópicas ${ }^{147} \mathrm{Sm} /{ }^{144} \mathrm{Nd}$ variando entre $0,106-0,122$ e ${ }^{143} \mathrm{Nd} /{ }^{144} \mathrm{Nd}$ variando entre 0,512164 0,512445 , similares às rochas do Arco Magmático de
Goiás, mostrando que estas pertencem ao mesmo (Navarro \& Zanardo 2006, Navarro et al. 2007).

\section{GEOLOGIA ESTRUTURAL E METAMORFIS-}

MO A foliação principal (Sn), de caráter regional, apresenta direção geral N-S a NNW/SSE e baixo a médio ângulo de mergulho para $\mathrm{W}$. No extremo norte da área, esta foliação está disposta, aproximadamente, na direção $\mathrm{E}-\mathrm{W}$, com mergulho baixo a médio para $\mathrm{S}$. Localmente, observa-se xistosidade (Sn-1), constituída pela orientação de minerais como filossilicatos, anfibólio, grãos de quartzo, feldspato etc., que marcam um bandamento composicional constituído por variações de porções lepidoblásticas e granoblásticas em metassedimentos, rochas metaultramáficas e gnaisses; por porções granoblásticas e nematoblásticas em rochas metamáficas, e pela intercalação, centimétrica a métrica de diferentes litotipos. A lineação mineral e/ou de estiramento apresenta baixo ângulo de mergulho para W e possui direção geral E-W (N76E/09SW). Os indicadores cinemáticos apontam sistematicamente transporte de topo para E.

As paragêneses e associações minerais presentes nas rochas da região, relacionadas ao pico do metamorfismo são típicas da fácies anfibolito. Nas rochas encaixantes (gnaisses e metassedimentos) as associações minerais relacionadas ao ápice metamórfico são marcadas pela presença de plagioclásio (oligoclásio-andesina) + feldspato potássico (ortoclásio parcial a totalmente triclinizado e microclínio) + biotita, plagioclásio + biotita + hornblenda, localmente com granada e rutilo associados e hornblenda + granada + plagioclásio + (estaurolita) + (cianita) em metassedimento pelítico, todas com quartzo e muscovita presente, sendo que em alguns tipos mais aluminosos a muscovita também aparenta estar em equilíbrio no ápice metamórfico. Essas associações indicam que as temperaturas mínimas estiveram entre $600^{\circ} \mathrm{C}$ e $750^{\circ} \mathrm{C}$ (campo de estabilidade da cianita) em regime de pressão compatível ou superior ao barroviano. A presença de mobilizados quartzo-plagioclásio gnaissificados indica que a temperatura mínima ultrapassou $650^{\circ} \mathrm{C}$ no auge metamórfico.

Nas rochas metaultramáficas, muito raramente, são observados restos de olivina e pseudomorfos (olivina e/ou piroxênio), com tramas sugestivas de reequilíbrio metamórfico de fácies anfibolito. No geral, observa-se apenas o produto da destruição total da mineralogia e das texturas primárias, restando associações minerais e paragêneses típicas da fácies xisto verde $\left(<550^{\circ} \mathrm{C}\right.$ e $\left.5,5 \mathrm{kbar}\right)$, constituídas por associações do tipo serpentina + talco, talco + clorita, normalmente com magnetita e carbonato.

Nas rochas metamáficas as assembleias metamórficas são representadas pelas associações: granada + plagioclásio + hornblenda e plagioclásio + hornblenda, sendo o rutilo e ilmenita os principais óxidos associados; quartzo, muscovita epidoto também ocorrem associados. Estas associações revelam que o ápice metamórfico atingiu condições de fácies anfibolito médio 
a superior, na zona da cianita. Aspectos texturais e microestruturais indicam que estas associações foram geradas no estágio inicial do desenvolvimento da foliação principal (Sn) ou mesmo antes (Sn-1).

\section{PETROGRAFIA DAS ROCHAS METAMÁFICAS/} METABÁSICAS As rochas metabásicas/metamáficas possuem granulação fina a média, raramente grossa, cor verde escura, textura nematoblástica a decussada, com ou sem domínios granoblásticos e estrutura levemente orientada a xistosa. Localmente apresentam bandamento descontínuo marcado por pequenas lentes quartzo/feldspáticas. São constituídas principalmente por hornblenda $(30-95 \%)$, plagioclásio $(0-60 \%)$ e quartzo $(0-15 \%)$, podendo ocorrer ainda como minerais essenciais granada $(0-20 \%)$, biotita $(0-20 \%)$, tremolita/actinolita $(0-15 \%)$, cummingtonita $(0-5 \%)$, epidoto/ clinozoisita $(0-6 \%)$, muscovita/sericita $(0-5 \%)$, clorita $(0-5 \%)$ e minerais opacos $(0-5 \%)$. Como minerais acessórios e ou secundários encontram-se ainda apatita, rutilo, titanita, zircão e allanita.

A hornblenda é o anfibólio mais frequente e ocorre orientada segundo a foliação em grau variado, em alguns litotipos apresenta baixo grau de orientação, é anedral a subedral. Apresenta pleocroísmo leve a forte com cor castanha, verde oliva a verde azulada e mais raramente verde amarelado pálido em " $\gamma$ ", evidenciando variação composicional; e dimensões médias submilimétricas $(0,4$ a $0,6 \mathrm{~mm})$. Pode constituir porfiroblastos $\mathrm{e}$, às vezes, poiquiloblastos (rico em inclusões retas ou não de plagioclásio, quartzo, rutilo, epidoto e opacos). A cummingtonita aparece como exsoluções lamelares segundo $\{001\}$; como intercrescimento longitudinal e porções arredondadas a irregulares, normalmente no núcleo dos cristais de hornblenda ou na matriz, formando pequenos cristais anedrais $(<0,2 \mathrm{~mm})$ dispersos. A actinolita, produto da transformação retrometamórfica de hornblenda, é anedral a subedral, frequentemente fibrosa e submilimétrica.

O plagioclásio é representado por labradorita, andesina, bytownita, oligoclásio e albita e ocorre intersticialmente ao anfibólio, normalmente com granulação média inferior, formando agregados lenticulares, ou como vênulas descontínuas em associação com quartzo, epidoto e granada, definindo bandamento composicional paralelo à foliação. Os cristais de plagioclásio são submilimétricos e, localmente, apresentam extinção ondulante. A albita é produto de retrometamorfismo constituindo coroas em cristais de plagioclásio mais cálcico, ou como pequenos cristais anedrais dispersos na lâmina junto a actinolita e epidoto. Sobre os cristais de plagioclásio é comum o desenvolvimento de pequenos cristais (anedrais a euedrais) ou massas irregulares de epidoto e palhetas relativamente grandes de mica branca.

A granada é subedral a anedral e apresenta dimensões milimétricas (podendo chegar a ultrapassar 1 $\mathrm{cm}$ de diâmetro). Ocorre dispersa, podendo constituir porfiroblastos e poiquiloblastos com inclusões de rutilo, ilmenita, quartzo, epidoto e plagioclásio. Localmente exibe bordas com alteração para biotita e clorita. Em alguns casos possui inclusões inequidimensionais, principalmente quartzo e minerais opacos, dispostos de forma orientada definindo difusa foliação interna.

$\mathrm{O}$ quartzo ocorre sob a forma de cristais pequenos, anedrais, dispersos homogeneamente entre os cristais de plagioclásio, como inclusões arredondadas em plagioclásio e anfibólio e formando concentrações difusas, que sugerem ter entrado no sistema (mobilizado) durante o desenvolvimento da foliação principal. Os cristais normalmente apresentam extinção ondulante moderada a forte acompanhada de recuperação com subgrãos bem definidos e relativamente grandes.

A biotita constitui palhetas submilimétricas tabulares a irregulares, normalmente bem orientadas, com pleocroísmo forte (amarelo pálido em $\alpha$ e marrom escuro em $\gamma$ ) e em alguns locais mostra textura de equilíbrio com o anfibólio, em outros se forma à custa deste $\mathrm{e}$ pode estar parcial a totalmente cloritizada.

A clorita aparece substituindo os outros minerais, sendo que nos tipos mais magnesianos chega a constituir até $5 \%$ do volume, forma palhetas relativamente grandes, submilimétricas, às vezes formando agregados com arranjo em leque, de cor verde pálido quase incolor, cor de interferência normal e apresenta geminação de repetição.

A mica branca constitui palhetas pequenas a relativamente grandes, podendo atingir $1 \mathrm{~mm}$ de comprimento, às vezes simplectítica, desenvolvida sobre plagioclásio, anfibólio, biotita, granada ou intersticialmente e disposta caoticamente ou com certa orientação.

O epidoto/clinozoisita é anedral a subedral, submilimétrico, ocorre disposto caoticamente ou parcialmente orientado, quando crescido sobre o plagioclásio apresenta dimensões menores e formas subedrais a anedrais ou massas irregulares amorfas e quando desenvolvidos intersticialmente ou sobre os máficos apresenta dimensões maiores e é anedral a subedral. Apresenta coloração verde pálido a amarelo, podendo em algumas rochas ultrapassar $5 \%$ do volume, constituindo epidoto anfibolito e epidoto-anfibólio xisto.

A titanita é comum, podendo em alguns casos perfazer cerca de $4 \%$ do volume, anedral a subedral e dispersa, localmente marcando trilhas ou envolvendo rutilo, ou minerais opacos, e as dimensões de seus cristais nunca ultrapassam $0,3 \mathrm{~mm}$. Os outros minerais (apatita, magnetita, ilmenita, allanita etc.) ocorrem dispersos pela rocha, com granulação fina e formas anedrais a euedrais.

Merece destaque especial a amostra (SG-155), que é constituída por plagioclásio $(\sim 50 \%)$, clinopiroxênio $(\sim 20 \%)$, quartzo $(\sim 10 \%)$, anfibólio $(\sim 10 \%)$, granada $(\sim 6 \%)$, minerais opacos $(\sim 5 \%)$ e ortopiroxênio $(<2 \%)$. O plagioclásio presente nesta lâmina ocorre sob a forma de pequenos cristais subtabulares a equidimensionais, normalmente com geminação bem desenvolvida. Os cristais de clinopiroxênio apresentam dimensões submilimétricas (podendo chegar a $0,5 \mathrm{~mm}$ ), são anedrais a subedrais e ocorrem dispostos de maneira orientada, ou não, segundo a foliação. Normalmente ocorrem com 
bordas alteradas para anfibólio (Fig. 2 - fotomicrografia 1A). O quartzo é anedral, submilimétrico, praticamente não exibe extinção ondulante e ocorre constituindo ribbons policristalinos. O anfibólio constitui pequenos cristais (submilimétricos), de cor verde oliva, anedrais e ocorrem na borda dos cristais de piroxênio. A granada forma cristais milimétricos $(<2 \mathrm{~mm}$ ), "límpidos" (sem inclusões), dispersos pela lâmina, com formas esféricas (Fig. 2 - fotomicrografia 1B). Alguns cristais apresentam bordas parcialmente cloritizadas. Os minerais opacos são anedrais, submilimétricos e ocorrem dispersos formando difusas trilhas e/ou em bandas orientadas. Pequenos cristais de ortopiroxênio, parcialmente alterados para anfibólio e opacos, ocorrem dispersos pela lâmina constituindo difusas trilhas. Completando a mineralogia, ocorrem cristais anedrais, submilimétricos de rutilo e ilmenita dispersos pela lâmina, que não chegam a representar $1 \%$ do volume.

Merece destaque também a presença localizada de leitos granoblásticos, observado em algumas lâminas, concordantes com a foliação gerando bandamento, constituídos por plagioclásio ou plagioclásio e quartzo, evidenciando mobilização local, pré- a cedodesenvolvimento da foliação. Em alguns casos, próximo ao contato com a encaixante, ocorre a formação de granada associada a mobilizados constituídos basicamente por plagioclásio e quartzo. Os aspectos texturais e mineralógicos, em especial a significativa presença de quartzo, sugere que a anatexia foi desencadeada pela entrada de fluido silicoso e o desenvolvimento da granada resultaria deste processo, que aparenta ter ocorrido no estágio inicial do desenvolvimento da foliação principal, ou mesmo antes do desenvolvimento de Sn-1.

Durante o desenvolvimento da foliação principal observa-se a recristalização do plagioclásio, quartzo, quebra e crescimento de hornblenda, formação de biotita e exsolução em anfibólio. Nos estágios finais ocorre a formação de actinolita, epidoto, albita, muscovita e clorita, fases que aparentam continuar formando-se após o encerramento do processo deformacional dúctil,

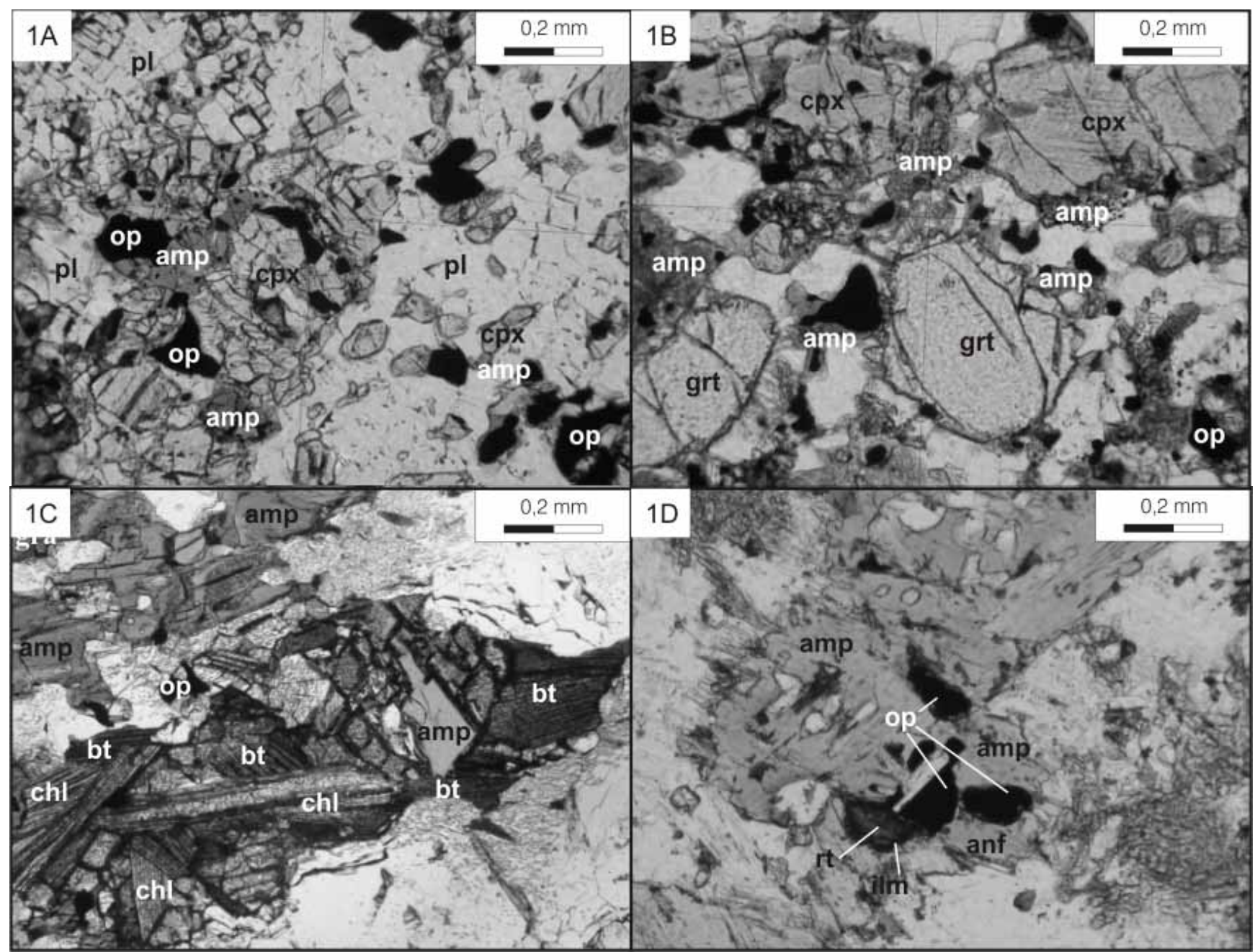

Figura 2 - Fotomicrografia 1 - Cristais de anfibólio e minerais opacos formados junto a cristais de clinopiroxênio. Fotomicrografia 1B. Cristais de anedrais de granada sem inclusões. Fotomicrografia 1C. Cristal de anfibólio alterado para clorita e biotita. Fotomicrografia 1D. Rutilo com borda de ilmenita amp = anfibólio, $b t=$ biotita, $\mathrm{chl}=$ clorita, cum $=$ cummingtonita, grt $=$ granada, ilm $=$ ilmenita,$m s=$ muscovita, op $=$ opaco, $p l=$ plagioclásio, $q t z=$ quartzo, $r t=$ rutilo. 
catalisado pela passagem de fluidos, gerando paragênese típica da fácies xisto verde.

A análise petrográfica não evidencia mudança significativa entre as paragêneses associadas às foliações Sn-1 e o estágio inicial de Sn, bem como no estilo deformacional, sugerindo que ambas resultaram de mesmo ciclo geotectônico, tratando-se de estágios de mesma deformação progressiva. Neste contexto, interpretou-se que as mudanças texturais/microestruturais pré a sin-desenvolvimento de Sn ocorreram de forma contínua, ou em estágios múltiplos sem contraste nítido entre eles, desde o auge metamórfico (pré- a cedo-Sn) catalisada por deformação, dominantemente, não coaxial e tangencial, em condição de progressiva diminuição de temperatura e pressão. Após o cessamento da deformação tangencial, ainda continuam a ocorrer transformações retrometamórficas catalisadas pela passagem de fluidos, aspecto demonstrado pela presença de clorita, muscovita/sericita e epidoto sem deformação e com disposição caótica, constituindo paragênese típica da fácies xisto verde.

QUÍMICA MINERAL Neste estudo foram selecionadas 6 amostras de rochas metamáficas/metabásicas (ME-48, ME-61, ME-149, PO-83, PO-100 e SG-155) para estudos de química mineral e cálculos termobarométricos, para avaliar as condições de metamorfismo. Para um melhor entendimento das condições de $P-T$ que afetaram a região, os dados obtidos com as rochas metamáficas foram comparados com duas amostras de gnaisses que afloram na região pertencente à Unidade Gnáissica (amostras PO-101 e PO-130). As lâminas selecionadas foram polidas no Laboratório de Laminação do Departamento de Petrologia e Metalogenia (DPM) do Instituto de Geociências e Ciências Exatas (IGCE), UNESP - Campus de Rio Claro, e levadas ao Laboratório de Microssonda Eletrônica do Instituto de Geociências da USP (IGc-USP), onde foram metalizadas com carbono. Os minerais que definem a paragênese do pico metamórfico foram analisados usando microssonda eletrônica da marca JEOL, modelo SUPERPROBE JXA-8600. As análises foram realizadas sob as seguintes condições: potencial de aceleração $15 \mathrm{KV}$, corrente de $20 \mathrm{nA}$ (nanoâmper), diâmetro de $5 \mu$ e tempo de exposição de $10 \mathrm{~s}$. Em cada amostra, dois a quatro grãos foram analisados em dois a três domínios diferentes, sendo analisados núcleos e bordas. As fórmulas estruturais dos minerais analisados foram calculadas através dos programas MINPET versão 2.02 (Richard 1995) e AXE (Powell \& Holland 1994).

Quimicamente as amostras analisadas correspondem a basaltos normais de natureza básica, predominando composições de basaltos subalcalinos com afinidade toleítica subalcalina. As rochas apresentam baixas concentrações de álcalis $\left(\mathrm{Na}_{2} \mathrm{O}=1,96-4,44\right.$ e $\left.\mathrm{K}_{2} \mathrm{O}=0,09-1,08\right)$, de $\mathrm{MnO}(<0,23 \%)$ e de $\mathrm{P}_{2} \mathrm{O}_{5}$ $(<0,24 \%)$. O conteúdo de $\mathrm{MgO}$ varia de 3,73 a $9,62 \%$, o de $\mathrm{Fe}_{2} \mathrm{O}_{3 \mathrm{~T}}$ varia de 9,59 a 14,26 e o de $\mathrm{CaO}$ entre 6,94 e $9,06 \%$ (Navarro et al. 2007).

Química mineral das rochas metamáficas/metabásicas Anfibólio: a maioria dos cristais de anfibólio analisados é classificada como cálcicos e apresentam uma composição variando entre magnésio-hornblenda a tschermakita e também como magnésio-hastingsita. Algumas análises caem no campo dos anfibólios $\mathrm{Mg}$ -Fe-Mn-Li e são classificadas como cummingtonita (Fig. 3A). As composições de cummingtonita ocorrem apenas na amostra PO-100 e estão relacionadas à borda dos cristais e devem corresponder a reequilíbrio retrometamórfico, contemporâneo ao desenvolvimento da foliação principal. Apresentam 0,002 a 0,007 a.p.u.f. de $\mathrm{Ti}$, entre 0,162 e 0,231 a.p.u.f. de $\mathrm{Al}^{\mathrm{IV}}$ e entre $0,095 \mathrm{e}$ 0,124 a.p.u.f. de $\mathrm{Al}^{\mathrm{VI}}$; contêm entre 0,015 e 0,023 de $\mathrm{Na}$ (M4) e entre 0,078 e 0,118 a.p.u.f. de Ca. Algumas análises da amostra ME-61 são classificadas como magnésio-hastingsita e formam, em relação aos conteúdos de álcalis totais e $\mathrm{Fe}^{+3}$, um grupo separado, refletindo a composição global da rocha, que é mais pobre em $\mathrm{Fe}, \mathrm{Ca}, \mathrm{Mg}$ e mais enriquecida em $\mathrm{Na}$ e $\mathrm{K}$ que as outras amostras (Navarro et al. 2007). As análises das amostras indicam que não existe um zoneamento composicional mesmo nos porfiroblastos analisados, apenas apresentam variações composicionais em campos diferentes. Os anfibólios cálcicos apresentam 0,007 a 0,161 a.p.u.f. de Ti, entre 0,945 e 2,109 a.p.u.f. de $\mathrm{Al}^{\mathrm{IV}} \mathrm{e}$ entre 0,630 e 1,776 a.p.u.f. de $\mathrm{Al}^{\mathrm{VI}}$, com maior variação de $\mathrm{Al}^{\mathrm{IV}}$, o que sugere que a substituição tschermak não é a única envolvida na variação composicional do anfibólio. Os conteúdos de $\mathrm{Na}$ e $\mathrm{K}$ variam entre 0,0170 e 0,4480 e 0,0010 e 0,1780 a.p.u.f. e o de Ca entre 1,441 e 1,909 a.p.u.f, sendo que o conteúdo de $\mathrm{Na}(\mathrm{M} 4)$ também é baixo (0,0150-0,306 a.p.u.f.).

Na amostra SG-155 os cristais de anfibólio ocorrem principalmente na borda dos cristais de piroxênio, indicando ser resultado de retrometamorfismo e apresentam 0,140-0,177 a.p.u.f. de Ti, entre 1,639 e 1,676 a.p.u.f. de $\mathrm{Al}^{\mathrm{IV}}$ e entre 0,598 e 0,624 a.p.u.f. de $\mathrm{Al}^{\mathrm{VI}}$, Na entre 0,363 e 0,391 a.p.u.f., K entre 0,156 e 0,178 a.p.u.f. e o de $\mathrm{Ca}$ entre 1,834 e 1,837 a.p.u.f, sendo que o conteúdo de $\mathrm{Na}(\mathrm{M} 4)$ é muito baixo $(0,087-0,088$ a.p.u.f.). As análises químicas representativas de anfibólios analisados estão na tabela 1 .

Plagioclásio: as análises de feldspatos mostram uma grande variação composicional, variando de oligoclásio a bytownita, predominando composições entre andesina e labradorita, não sendo observada nenhuma zonação química concêntrica nos grãos, apenas ocorrendo porções de composições diferentes nos cristais (Fig. 3B). Na amostra ME-48 os cristais de plagioclásio analisados apresentam composição homogênea de labradorita $\left(a_{38,3-46,3}\right)$, sendo os valores mais ricos em albita relacinados principalmente à borda dos cristais. Os grãos analisados na amostra ME-61 apresentam composição que varia entre oligoclásio $\left(a_{73,3-77,5}\right)$ e andesina $\left(a_{61,4-64,4}\right)$, não sendo possível estabelecer qual a relação composicional entre núcleo e borda dos grãos, já que ocorrem grãos de composição de oligoclásio tanto na borda como no núcleo. Na amostra PO-83 os cristais de plagioclásio exibem duas composições distintas: a maioria dos cristais possui composição de labradorita $\left(\mathrm{ab}_{37,4-44,1}\right)$ e alguns cristais de dimensões menores possuem composição de 
(A)
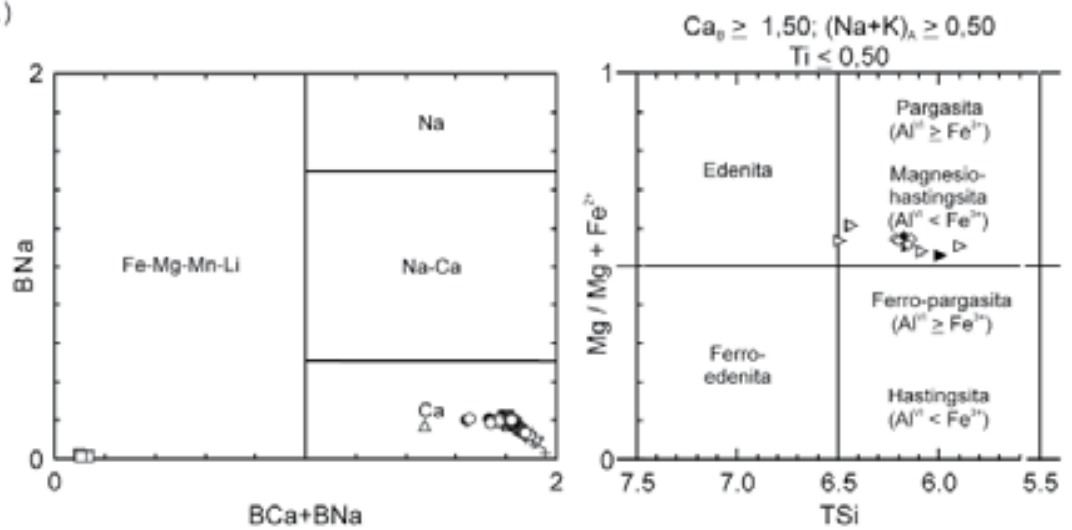

(B)

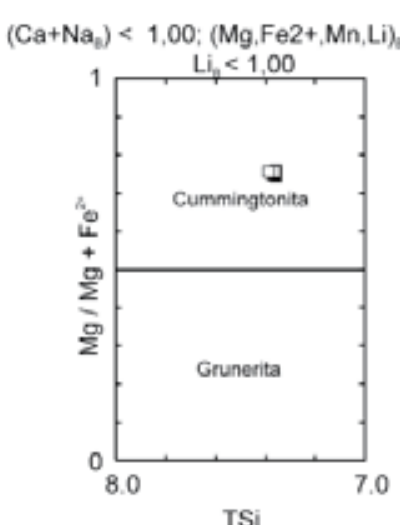

TSi

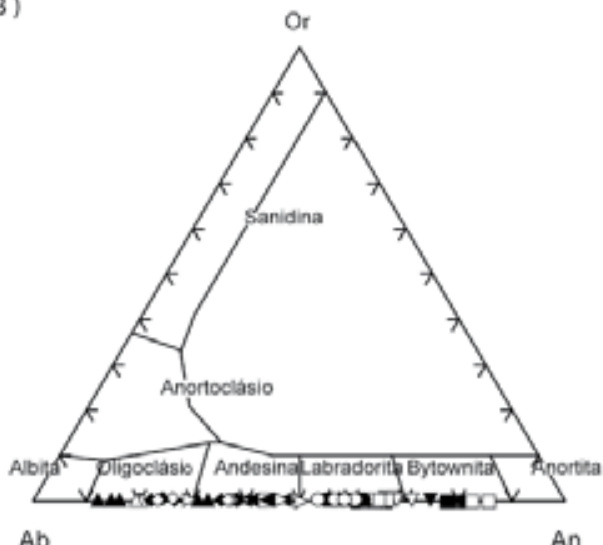

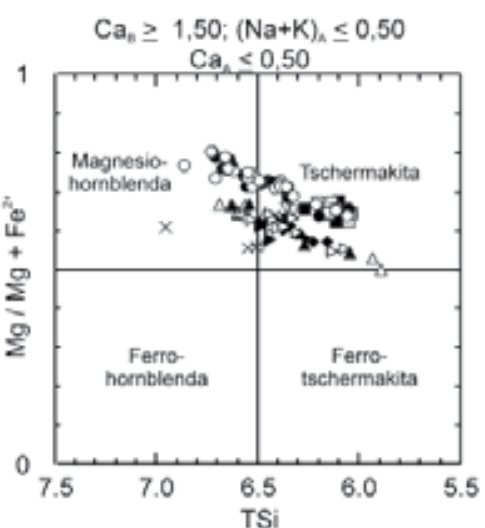

(C)

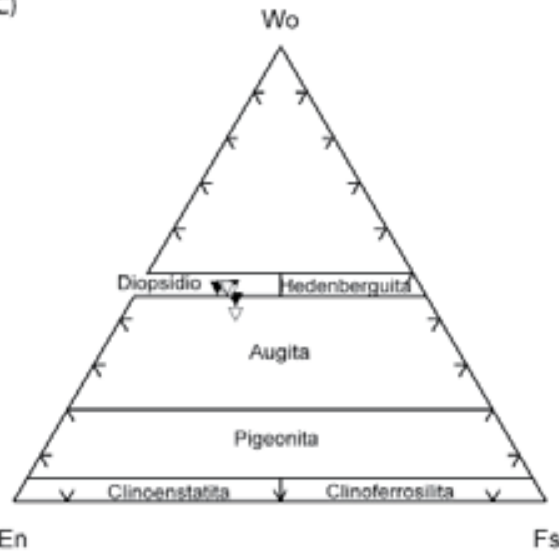

(D)

PO- $100 \mathrm{C} 3$

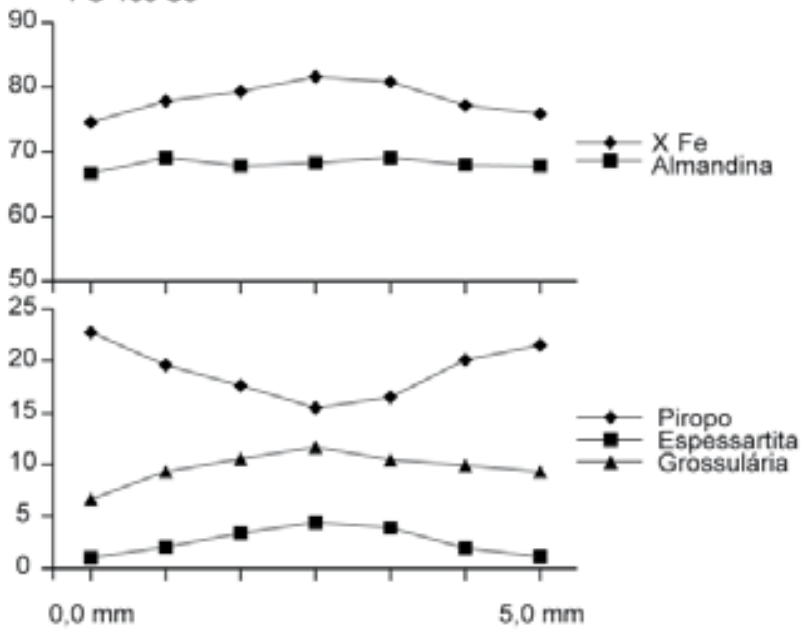

SG-155

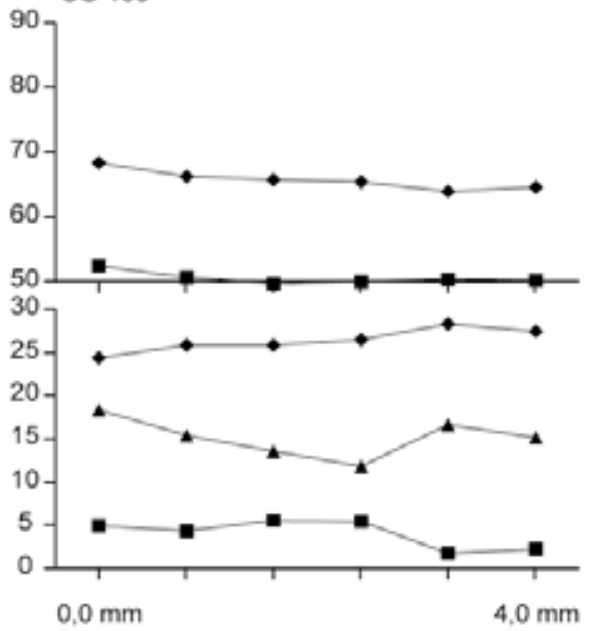

SIMBOLOS

- ME-48 núcleo

ME-48 borda $\checkmark$ ME-61 núcleo

- ME-61 borda $\triangle \mathrm{PO}-83$ núcleo

A PO-83 borda
口 PO-100 núcleo

PO-100 borda $\nabla$ SG-155 nùcleo

$\nabla$ SG-155 borda
- ME-149 núcleo $\times$ Crm-29 núcleo $D$ ME-149 borda +Crm-29 borda

Figura 3 - (A) Diagrama de classificação dos anfibólios analisados (Leake et al. 1997). (B) Diagrama de classificação dos feldspatos analisados. (C) Diagrama de classificação de piroxênio (Morimoto, 1988). (D) Perfis de granadas analisadas (amostra PO-100 e amostra SG-155). 
Tabela 1 - Análises químicas representativas de anfibólios analisados. $n=$ núcleo, $b=$ borda. Os átomos por unidade de fórmula foram calculados na base para 23 oxigênios.

\begin{tabular}{|c|c|c|c|c|c|c|c|c|c|c|c|c|c|}
\hline Amostra & ME-48 & ME-48 & $\begin{array}{c}\text { ME- } \\
149 \\
\end{array}$ & $\begin{array}{c}\text { ME- } \\
149 \\
\end{array}$ & PO-83 & PO-83 & $\begin{array}{c}\text { PO- } \\
100 \mathrm{~B}\end{array}$ & $\begin{array}{c}\text { PO- } \\
100 \mathrm{~B}\end{array}$ & $\begin{array}{c}\text { PO- } \\
100 \mathrm{~B}\end{array}$ & ME-61 & ME-61 & $\begin{array}{l}\text { SG- } \\
155\end{array}$ & $\begin{array}{l}\text { SG- } \\
155\end{array}$ \\
\hline Análise & $\mathrm{b}$ & $\mathrm{n}$ & $\mathrm{b}$ & $\mathrm{n}$ & $\mathrm{n}$ & $\mathrm{b}$ & $\mathrm{b}$ & $\mathrm{N}$ & B & $\mathrm{n}$ & $\mathrm{n}$ & $\mathrm{n}$ & $\mathrm{n}$ \\
\hline $\mathrm{SiO}_{2}$ & 44,291 & 44,798 & 42,545 & 42,865 & 45,547 & 41,868 & 43,004 & 42,980 & 42,679 & 41,355 & 41,639 & 42,936 & 42,164 \\
\hline $\mathrm{TiO}_{2}$ & 0,597 & 0,621 & 0,775 & 0,615 & 1,105 & 0,241 & 0,435 & 0,439 & 0,513 & 0,540 & 0,400 & 1,255 & 1,099 \\
\hline $\mathrm{Al}_{2} \mathrm{O}_{3}$ & 16,567 & 15,165 & 14,407 & 13,926 & 14,035 & 20,732 & 19,266 & 17,833 & 19,668 & 15,207 & 14,747 & 12,822 & 13,022 \\
\hline $\mathrm{FeO}$ & 11,656 & 11,482 & 15,078 & 15,610 & 13,243 & 14,278 & 13,234 & 14,006 & 13,847 & 17,183 & 16,729 & 14,328 & 14,319 \\
\hline $\mathrm{Cr}_{2} \mathrm{O}_{3}$ & 0,128 & 0,038 & 0,043 & 0,000 & 0,000 & 0,000 & 0,000 & 0,000 & 0,000 & 0,000 & 0,000 & 0,000 & 0,000 \\
\hline $\mathrm{MnO}$ & 0,264 & 0,217 & 0,096 & 0,208 & 0,230 & 0,257 & 0,035 & 0,093 & 0,064 & 0,377 & 0,384 & 0,239 & 0,203 \\
\hline $\mathrm{MgO}$ & 11,761 & 12,411 & 10,367 & 10,904 & 11,145 & 8,213 & 9,960 & 10,546 & 9,487 & 9,424 & 9,579 & 11,473 & 11,212 \\
\hline $\mathrm{CaO}$ & 10,655 & 10,767 & 10,478 & 10,527 & 10,759 & 11,225 & 10,806 & 10,354 & 10,647 & 10,774 & 10,887 & 11,568 & 11,430 \\
\hline $\mathrm{Na}_{2} \mathrm{O}$ & 1,944 & 1,924 & 1,987 & 1,987 & 1,448 & 1,754 & 1,593 & 1,721 & 1,595 & 1,949 & 1,958 & 1,263 & 1,344 \\
\hline $\mathrm{K}_{2} \mathrm{O}$ & 0,227 & 0,226 & 0,397 & 0,447 & 0,479 & 0,409 & 0,230 & 0,188 & 0,244 & 0,540 & 0,564 & 0,827 & 0,902 \\
\hline $\mathrm{F}$ & 0,075 & 0,000 & 0,056 & 0,000 & 0,021 & 0,000 & 0,136 & 0,001 & 0,037 & 0,118 & 0,095 & 0,078 & 1,333 \\
\hline $\mathrm{Cl}$ & 0,046 & 0,043 & 0,023 & 0,000 & 0,027 & 0,000 & 0,016 & 0,009 & 0,001 & 0,000 & 0,000 & 0,045 & 0,000 \\
\hline O-F-CL & 0,040 & 0,010 & 0,030 & 0,000 & 0,010 & 0,000 & 0,060 & 0,000 & 0,020 & 0,050 & 0,040 & 0,040 & 0,560 \\
\hline $\mathrm{O}-\mathrm{F}$ & 0,030 & 0,000 & 0,020 & 0,000 & 0,010 & 0,000 & 0,060 & 0,000 & 0,020 & 0,050 & 0,040 & 0,030 & 0,560 \\
\hline $\mathrm{O}-\mathrm{CL}$ & 0,010 & 0,010 & 0,010 & 0,000 & 0,010 & 0,000 & 0,000 & 0,000 & 0,000 & 0,000 & 0,000 & 0,010 & 0,000 \\
\hline$\Sigma$ Óxidos & 98,080 & 97,650 & 96,312 & 97,089 & 98,040 & 98,980 & 98,720 & 98,170 & 98,780 & 97,470 & 96,980 & 96,830 & 97,030 \\
\hline $\mathrm{TSi}$ & 6,351 & 6,447 & 6,340 & 6,322 & 6,599 & 6,047 & 6,154 & 6,175 & 6,111 & 6,144 & 6,216 & 6,361 & 6,324 \\
\hline TAl & 1,649 & 1,553 & 1,660 & 1,678 & 1,401 & 1,953 & 1,846 & 1,825 & 1,889 & 1,856 &, 784 & 1,639 & 1,676 \\
\hline $\mathrm{TFe}^{3+}$ & - & - & - & - & - & - & - & - & - & - & - & - & - \\
\hline $\mathrm{TTi}$ & - & - & - & - & - & - & - & - & - & - & - & - & - \\
\hline$\Sigma \mathrm{T}$ & 8,000 & 8,000 & 8,000 & 8,000 & 8,000 & 8,000 & 8,000 & 8,000 & 8,000 & 8,000 & 8,000 & 8,000 & 8,000 \\
\hline CAl & 1,148 & 1,017 & 0,868 & 0,741 & 0,994 & 1,573 & 1,401 & 1,192 & 1,427 & 0,804 & 0,808 & 0,598 & 0,624 \\
\hline $\mathrm{CCr}$ & 0,014 & 0,004 & 0,005 & 0,000 & - & - & - & - & - & - & - & - & - \\
\hline $\mathrm{CFe}^{3+}$ & 0,377 & 0,368 & 0,423 & 0,526 & 0,281 & 0,236 & 0,396 & 0,558 & 0,426 & 0,570 & 0,488 & 0,417 & 0,415 \\
\hline $\mathrm{CTi}$ & 0,064 & 0,067 & 0,087 & 0,068 & 0,120 & 0,026 & 0,047 & 0,047 & 0,055 & 0,060 & 0,045 & 0,140 & 0,124 \\
\hline $\mathrm{CMg}$ & 2,514 & 2,663 & 2,303 & 2,398 & 2,407 & 1,768 & 2,125 & 2,259 & 2,025 & 2,087 & 2,132 & 2,534 & 2,507 \\
\hline $\mathrm{CFe}^{2+}$ & 0,866 & 0,868 & 1,309 & 1,255 & 1,183 & 1,381 & 1,029 & 0,939 & 1,063 & 1,455 & 1,504 & 1,296 & 1,317 \\
\hline $\mathrm{CMn}$ & 0,016 & 0,013 & 0,006 & 0,013 & 0,014 & 0,016 & 0,002 & 0,006 & 0,004 & 0,023 & 0,024 & 0,015 & 0,013 \\
\hline $\mathrm{CCa}$ & - & - & - & - & - & - & - & - & - & - & - & - & - \\
\hline$\Sigma \mathrm{C}$ & 5,000 & 5,000 & 5,000 & 5,000 & 5,000 & 5,000 & 5,000 & 5,000 & 5,000 & 5,000 & 5,000 & 5,000 & 5,000 \\
\hline $\mathrm{BMg}$ & - & - & - & - & - & - & - & - & - & - & - & - & - \\
\hline $\mathrm{BFe}^{2+}$ & 0,155 & 0,146 & 0,148 & 0,145 & 0,141 & 0,107 & 0,159 & 0,186 & 0,169 & 0,110 & 0,097 & 0,061 & 0,063 \\
\hline $\mathrm{BMn}$ & 0,016 & 0,013 & 0,006 & 0,013 & 0,014 & 0,016 & 0,002 & 0,006 & 0,004 & 0,024 & 0,025 & 0,015 & 0,013 \\
\hline $\mathrm{BCa}$ & 1,637 & 1,660 & 1,673 & 1,664 & 1,670 & 1,737 & 1,657 & 1,594 & 1,633 & 1,715 & 1,741 & 1,836 & 1,837 \\
\hline $\mathrm{BNa}$ & 0,192 & 0,180 & 0,173 & 0,178 & 0,175 & 0,140 & 0,182 & 0,215 & 0,194 & 0,151 & 0,137 & 0,087 & 0,087 \\
\hline$\Sigma \mathrm{B}$ & 2,000 & 2,000 & 2,000 & 2,000 & 2,000 & 2,000 & 2,000 & 2,000 & 2,000 & 2,000 & 2,000 & 2,000 & 2,000 \\
\hline $\mathrm{ACa}$ & - & - & - & - & - & - & - & - & - & - & - & - & - \\
\hline $\mathrm{ANa}$ & 0,348 & 0,357 & 0,401 & 0,390 & 0,232 & 0,352 & 0,260 & 0,265 & 0,249 & 0,410 & 0,429 & 0,276 & 0,304 \\
\hline $\mathrm{AK}$ & 0,042 & 0,041 & 0,075 & 0,084 & 0,089 & 0,075 & 0,042 & 0,034 & 0,045 & 0,102 & 0,107 & 0,156 & 0,173 \\
\hline$\sum \mathrm{A}$ & 0,390 & 0,398 & 0,476 & 0,474 & 0,321 & 0,427 & 0,302 & 0,299 & 0,293 & 0,512 & 0,537 & 0,432 & 0,476 \\
\hline$\Sigma$ Cátion & 15,390 & 15,398 & 15,476 & 15,474 & 15,321 & 15,427 & 15,302 & 15,299 & 15,293 & 15,512 & 15,537 & 15,432 & 15,476 \\
\hline $\mathrm{CCl}$ & 0,011 & 0,010 & 0,006 & 0,000 & 0,007 & 0,000 & 0,004 & 0,002 & 0,000 & 0,000 & 0,000 & 0,011 & 0,000 \\
\hline $\mathrm{CF}$ & 0,034 & 0,000 & 0,026 & 0,000 & 0,010 & 0,000 & 0,062 & 0,000 & 0,017 & 0,055 & 0,045 & 0,037 & 0,632 \\
\hline \multicolumn{14}{|l|}{$\mathrm{OH}$} \\
\hline$\sum$ Oxi & 23,109 & 23,094 & 23,056 & 23,011 & 23,131 & 23,098 & 23,083 & 23,052 & 23,087 & 23,000 & 23,000 & 23,000 & 23,000 \\
\hline
\end{tabular}


oligoclásio/andesina $\left(\mathrm{ab}_{794-87,6}\right)$ tanto na borda como no núcleo. A amostra PO-100 também apresenta uma grande variação composicional, a maioria dos cristais analisados possui composição de labradorita $\left(\mathrm{ab}_{33,3-39,3}\right)$, seguida de composição andesina $\left(\mathrm{ab}_{5630-57,5}\right)$ e alguns cristais apresentam composição de bytownita $\left(\mathrm{ab}_{14,4-22.3}\right)$ tanto na borda como no núcleo dos cristais, não sendo possível estabelecer qual a relação composicional entre núcleo e borda dos grãos. A amostra SG-155 apresenta pouca variação na composição dos feldspatos analisados, mostrando uma variação entre labradorita e bytownita $\left(\mathrm{ab}_{25,4-}\right.$ ${ }_{37,00}$ predominando composições entre $\mathrm{ab}_{31,4-33,6}$. Cabe ressaltar que em todos os casos a textura evidencia equilíbrio ou reequilíbrio. Análises químicas representativas de plagioclásio estão na tabela 2.

Clinopiroxênio: os cristais de clinopiroxênio analisados são classificados como cálcicos e apresentam composição de diopsídio (Fig. 3C), não exibindo zoneamento composicional. Contêm baixos teores de $\mathrm{Ti}$ (entre 0,01 e 0,02 a.p.u.f.), $\mathrm{Na}$ (entre 0,03 e 0,05 a.p.u.f.), $\mathrm{Al}^{\mathrm{IV}}$ (entre 0,09 e 0,19 a.p.u.f.) e entre 0,27 e 0,38 a.p.u.f. de $\mathrm{Fe}^{2+}$. O conteúdo de $\mathrm{Mg}$ varia entre 0,66 e 0,73 a.p.u.f. e o de Ca entre 0,76 e 0,90 a.p.u.f. As análises químicas representativas de cristais de clinopiroxênio analisados estão na tabela 3.

Granada: os cristais de granada da amostra PO100 apresentam composição dominada pela molécula almandina, seguida por piropo, espessartita e grossulária. Ocorre um aumento de $\mathrm{Mg}$ em direção às bordas

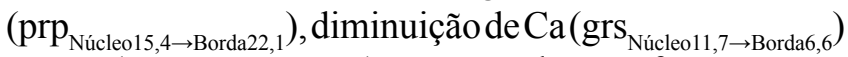
e Mn ( $\operatorname{sps}_{\text {Núcleo } 4,4 \rightarrow \text { Bordal }, 1}$ ), mostrando um fraco zoneamento composicional (Fig. 3D), e um leve enriquecimento no teor de $\mathrm{Fe}$, seguido de uma diminuição do teor na borda $\left(\operatorname{alm}_{\text {Núcleo67,8 } \rightarrow 69,1 \rightarrow B \text { Borda66,7 }}\right)$. Na amostra SG-155,

Tabela 2 - Análises químicas representativas de plagioclásio. $n=$ núcleo, $b=$ borda. Os átomos por unidade de fórmula foram calculados na base para 8 oxigênios.

\begin{tabular}{|c|c|c|c|c|c|c|c|c|c|c|c|c|}
\hline Amostra & ME-48 & ME-48 & ME-61 & ME-61 & ME-149 & ME-149 & PO-83 & PO-83 & PO-100 & PO-100 & SG-155 & SG-155 \\
\hline \multirow[t]{2}{*}{ Análise } & $\mathrm{b}$ & $\mathrm{n}$ & $\mathrm{b}$ & $\mathrm{n}$ & $\mathrm{n}$ & $\mathrm{b}$ & $\mathrm{n}$ & $\mathrm{b}$ & $\mathrm{n}$ & $\mathrm{n}$ & $\mathrm{n}$ & $\mathrm{n}$ \\
\hline & & & & & $29 \mathrm{c} 2$ & $33 \mathrm{c} 5$ & & & & & & \\
\hline $\mathrm{SiO}_{2}$ & 52,420 & 52,670 & 58,228 & 58,375 & 57,248 & 56,379 & 53,830 & 66,530 & 45,990 & 56,460 & 52,050 & 49,430 \\
\hline $\mathrm{TiO}_{2}$ & 0,050 & 0,030 & 0,009 & 0,003 & 0,000 & 0,001 & 0,000 & 0,050 & 0,000 & 0,010 & 0,030 & 0,000 \\
\hline $\mathrm{Al}_{2} \mathrm{O}_{3}$ & 30,240 & 29,670 & 25,804 & 25,744 & 27,841 & 28,269 & 29,210 & 21,290 & 34,090 & 26,780 & 29,810 & 32,150 \\
\hline $\mathrm{Fe}_{2} \mathrm{O}_{3}$ & 0,000 & 0,000 & 0,000 & 0,000 & 0,109 & 0,070 & 0,030 & 0,240 & 0,220 & 0,020 & 0,140 & 0,220 \\
\hline $\mathrm{FeO}$ & 0,020 & 0,020 & 0,078 & 0,025 & 0,000 & 0,000 & 0,000 & 0,000 & 0,000 & 0,000 & 0,000 & 0,000 \\
\hline $\mathrm{MnO}$ & 0,020 & 0,000 & 0,013 & 0,000 & 0,060 & 0,000 & 0,000 & 0,000 & 0,000 & 0,030 & 0,000 & 0,000 \\
\hline $\mathrm{MgO}$ & 0,010 & 0,000 & 0,000 & 0,000 & 0,013 & 0,000 & 0,010 & 0,000 & 0,010 & 0,010 & 0,000 & 0,010 \\
\hline $\mathrm{BaO}$ & 0,000 & 0,000 & 0,000 & 0,000 & 0,000 & 0,000 & 0,000 & 0,000 & 0,000 & 0,000 & 0,000 & 0,000 \\
\hline $\mathrm{CaO}$ & 12,850 & 12,670 & 8,147 & 7,857 & 9,035 & 9,850 & 11,810 & 2,510 & 17,090 & 9,110 & 12,570 & 15,240 \\
\hline $\mathrm{Na}_{2} \mathrm{O}$ & 4,430 & 4,570 & 7,214 & 7,322 & 6,407 & 6,082 & 4,860 & 10,060 & 1,590 & 6,500 & 4,100 & 2,870 \\
\hline $\mathrm{K}_{2} \mathrm{O}$ & 0,040 & 0,030 & 0,055 & 0,065 & 0,059 & 0,024 & 0,030 & 0,060 & 0,000 & 0,030 & 0,070 & 0,040 \\
\hline$\sum$ óxidos & 100,080 & 99,660 & 99,550 & 99,390 & 100,77 & 100,67 & 99,780 & 100,740 & 98,990 & 98,950 & 98,770 & 99,960 \\
\hline $\mathrm{Si}$ & 2,375 & 2,395 & 2,617 & 2,626 & 2,546 & 2,516 & 2,437 & 2,842 & 2,134 & 2,56 & 2,386 & 2,258 \\
\hline $\mathrm{Al}$ & 1,616 & 1,591 & 1,367 & 1,365 & 1,460 & 1,487 & 1,558 & 1,141 & 1,865 & 1,432 & 1,611 & 1,732 \\
\hline $\mathrm{F}^{3+}$ & 0,001 & 0,001 & 0,003 & 0,001 & 0,004 & 0,002 & 0,001 & 0,006 & 0,008 & 0,001 & 0,005 & 0,007 \\
\hline $\mathrm{Ti}$ & 0,002 & 0,001 & 0,000 & 0,000 & 0,000 & 0,000 & 0,000 & 0,001 & 0,000 & 0,000 & 0,001 & 0,000 \\
\hline $\mathrm{Fe}^{2+}$ & 0,000 & 0,000 & 0,000 & 0,000 & 0,000 & 0,000 & 0,000 & 0,000 & 0,000 & 0,000 & 0,000 & 0,000 \\
\hline $\mathrm{Mn}$ & 0,001 & 0,000 & 0,000 & 0,000 & 0,002 & 0,000 & 0,000 & 0,000 & 0,000 & 0,001 & 0,000 & 0,000 \\
\hline $\mathrm{Mg}$ & 0,001 & 0,000 & 0,000 & 0,000 & 0,001 & 0,000 & 0,001 & 0,005 & 0,001 & 0,001 & 0,000 & 0,001 \\
\hline $\mathrm{Ba}$ & 0,000 & 0,000 & 0,000 & 0,000 & 0,000 & 0,000 & 0,000 & 0,000 & 0,000 & 0,000 & 0,000 & 0,000 \\
\hline $\mathrm{Ca}$ & 0,624 & 0,618 & 0,392 & 0,379 & 0,431 & 0,471 & 0,573 & 0,151 & 0,85 & 0,442 & 0,618 & 0,746 \\
\hline $\mathrm{Na}$ & 0,389 & 0,403 & 0,629 & 0,639 & 0,553 & 0,526 & 0,427 & 0,87 & 0,143 & 0,572 & 0,364 & 0,254 \\
\hline $\mathrm{K}$ & 0,002 & 0,002 & 0,003 & 0,004 & 0,003 & 0,001 & 0,002 & 0,004 & 0,000 & 0,002 & 0,004 & 0,002 \\
\hline$\sum$ cátions & 5,011 & 5,010 & 5,013 & 5,013 & 5,000 & 5,003 & 4,998 & 5,020 & 5,001 & 5,010 & 4,989 & 5,000 \\
\hline$\% a b$ & 38,325 & 39,394 & 61,426 & 62,524 & 56,028 & 52,705 & 42,615 & 84,878 & 14,401 & 56,299 & 36,917 & 25,349 \\
\hline$\%$ an & 61,478 & 60,411 & 38,281 & 37,084 & 43,668 & 47,194 & 57,186 & 14,732 & 85,599 & 43,504 & 62,677 & 74,451 \\
\hline$\%$ or & 0,197 & 0,196 & 0,293 & 0,391 & 0,304 & 0,100 & 0,200 & 0,390 & 0,000 & 0,197 & 0,406 & 0,200 \\
\hline
\end{tabular}


Tabela 3 - Análises químicas representativas de clinopiroxênio. Os átomos por unidade de fórmula foram calculados na base para 6 oxigênios.

\begin{tabular}{|c|c|c|c|c|c|c|c|c|}
\hline Amostra & SG-155 & SG-155 & SG-155 & SG-155 & SG-155 & SG-155 & SG-155 & SG-155 \\
\hline $\mathrm{SiO}_{2}$ & 48,77 & 48,79 & 47,88 & 48,88 & 48,83 & 49,31 & 49,05 & 50,66 \\
\hline $\mathrm{TiO}_{2}$ & 0,56 & 0,39 & 0,7 & 0,38 & 0,46 & 0,32 & 0,47 & 0,22 \\
\hline $\mathrm{Al}_{2} \mathrm{O}_{3}$ & 4,93 & 5,33 & 6,36 & 4,92 & 5,07 & 4,39 & 5,01 & 2,97 \\
\hline $\mathrm{Cr}_{2} \mathrm{O}_{3}$ & 0,08 & 0,000 & 0,000 & 0,000 & 0,000 & 0,000 & 0,000 & 0,000 \\
\hline $\mathrm{Fe}_{2} \mathrm{O}_{3}$ & 4,06 & 2,78 & 3,73 & 2,93 & 3,25 & 4,03 & 3,82 & 2,6 \\
\hline $\mathrm{FeO}$ & 6,25 & 9,49 & 7,63 & 7,26 & 6,67 & 5,75 & 6,19 & 6,36 \\
\hline $\mathrm{MnO}$ & 0,4 & 0,42 & 0,42 & 0,43 & 0,28 & 0,28 & 0,33 & 0,34 \\
\hline $\mathrm{MgO}$ & 11,82 & 12,38 & 11,68 & 11,95 & 11,93 & 12,44 & 12,29 & 13,03 \\
\hline $\mathrm{CaO}$ & 21,98 & 18,71 & 19,99 & 21,11 & 21,82 & 22,15 & 21,85 & 22,41 \\
\hline $\mathrm{Na}_{2} \mathrm{O}$ & 0,63 & 0,58 & 0,73 & 0,59 & 0,57 & 0,57 & 0,57 & 0,46 \\
\hline $\mathrm{K}_{2} \mathrm{O}$ & 0,01 & 0,02 & 0,01 & 0,02 & 0,000 & 0,02 & 0,01 & 0,000 \\
\hline$\Sigma$ Óxidos & 99,48 & 98,9 & 99,13 & 98,47 & 98,86 & 99,26 & 99,58 & 99,04 \\
\hline $\mathrm{Si}$ & 1,839 & 1,852 & 1,812 & 1,859 & 1,848 & 1,857 & 1,843 & 1,908 \\
\hline $\mathrm{Ti}$ & 0,016 & 0,011 & 0,02 & 0,011 & 0,013 & 0,009 & 0,013 & 0,006 \\
\hline $\mathrm{Al}$ & 0,219 & 0,239 & 0,284 & 0,221 & 0,226 & 0,195 & 0,222 & 0,132 \\
\hline $\mathrm{Cr}$ & 0,002 & 0,000 & 0,000 & 0,000 & 0,000 & 0,000 & 0,000 & 0,000 \\
\hline $\mathrm{Fe}^{3+}$ & 0,115 & 0,079 & 0,106 & 0,084 & 0,092 & 0,114 & 0,108 & 0,074 \\
\hline $\mathrm{Fe}^{2+}$ & 0,197 & 0,301 & 0,241 & 0,231 & 0,211 & 0,181 & 0,194 & 0,200 \\
\hline $\mathrm{Mn}$ & 0,013 & 0,013 & 0,013 & 0,014 & 0,009 & 0,009 & 0,01 & 0,011 \\
\hline $\mathrm{Mg}$ & 0,664 & 0,700 & 0,659 & 0,677 & 0,673 & 0,698 & 0,688 & 0,731 \\
\hline $\mathrm{Ca}$ & 0,888 & 0,761 & 0,811 & 0,86 & 0,885 & 0,894 & 0,88 & 0,904 \\
\hline $\mathrm{Na}$ & 0,046 & 0,043 & 0,053 & 0,043 & 0,042 & 0,041 & 0,042 & 0,034 \\
\hline $\mathrm{K}$ & 0,001 & 0,001 & 0,000 & 0,001 & 0,000 & 0,001 & 0,000 & 0,000 \\
\hline$\Sigma$ Total & 4,00 & 4,00 & 4,00 & 4,00 & 4,00 & 4,00 & 4,00 & 4,00 \\
\hline
\end{tabular}

o zoneamento composicional não é marcante, apenas observa-se que a composição dominante é a molécula de almandina, seguida por piropo, grossulária e espessartita. Este cristal exibe fraco aumento no teor de Fe $\left(\operatorname{alm}_{\text {Núcleo49,6 } \rightarrow \text { Borda52,4 }}\right)$, e em Ca $\left(\right.$ grs $\left._{\text {Núcleo1 1, } \rightarrow \rightarrow \text { Borda 18,2 }}\right)$ e empobrecimento em $\mathrm{Mn}\left(\mathrm{sps}_{\mathrm{Núcleo5}, 5 \rightarrow \mathrm{Bord} 2,2,}\right)$, do núcleo para a borda (Fig. 3D). O Mg apresenta uma variação muito leve do núcleo para a borda, sofrendo uma leve diminuição do núcleo em direção à borda, seguido de um aumento do teor na borda $\left(\operatorname{prp}_{\text {Núcleo26,3 } \rightarrow 24,3 \rightarrow \text { Borda27,4 }}\right)$. A análise representativa de cristal de granada analisado (amostra PO-100) está na tabela 4.

METAMORFISMO E TERMOBAROMETRIA OS cálculos das condições de $P$ e $T$ do metamorfismo nas rochas metamáficas foram feitos com o programa PTMAFIC (Soto \& Soto 1993) e HB-PLAG (Holland \& Blundy 1994). A temperatura foi calculada segundo o método de Blundy \& Holland (1990) e Holland \& Blundy (1994), que utilizam a composição do par plagioclásio + anfibólio. Os valores das condições de $P$ foram obtidos segundo o método proposto por Kohn \& Spear
$(1989,1990)$, utilizando a associação mineral granada + plagioclásio + anfibólio. O geotermômetro clinopiroxênio + granada e clinopiroxênio + plagioclásio + granada não foram utilizados porque essas fases minerais não apresentam relações de contato entre si, e o clinopiroxênio mostra nítido desequilíbrio originando anfibólio e/ou epidoto, o que inviabiliza o seu uso. Em todas as secções delgadas observaram-se reações retrometamórficas e que estas ocorreram em grau variado de leve a intenso, demonstrando que o processo foi penetrativo, porém com intensidade variada. Desta forma, para os cálculos termobarométricos selecionaram-se as seções menos afetadas, com evidências de que o equilíbrio não foi afetado de forma significativa. A tabela 5 apresenta o resumo das associações minerais observadas e utilizadas no cálculo das condições de $P$ e $T$.

As associações minerais das rochas metamáficas/ metabásicas relacionadas ao pico do metamorfismo são típicas da fácies anfibolito, caracterizadas pela presença de anfibólio + plagioclásio + (quartzo) + (rutilo) + (ilmenita), granada + anfibólio + plagioclásio + (quartzo) + (rutilo) + (ilmenita). A exceção é a amostra SG-155 que mostra a associação plagioclásio + clinopiroxênio + 
Tabela 4 - Análises químicas e fórmula estrutural de cristal de granada (PO-100) analisado. Os átomos por unidade de fórmula foram calculados na base para 12 oxigênios.

\begin{tabular}{|c|c|c|c|c|c|c|c|}
\hline PO-100 C3 & PO-100 & PO-100 & PO-100 & PO-100 & PO-100 & PO-100 & PO-100 \\
\hline $\mathrm{SiO}_{2}$ & 37,070 & 37,540 & 36,730 & 37,150 & 37,130 & 37,190 & 37,440 \\
\hline $\mathrm{TiO}_{2}$ & 0,080 & 0,020 & 0,170 & 0,030 & 0,030 & 0,020 & 0,000 \\
\hline $\mathrm{Al}_{2} \mathrm{O}_{3}$ & 21,330 & 21,630 & 21,230 & 21,300 & 21,190 & 21,220 & 21,630 \\
\hline $\mathrm{Cr}_{2} \mathrm{O}_{3}$ & 0,000 & 0,010 & 0,000 & 0,010 & 0,000 & 0,000 & 0,000 \\
\hline $\mathrm{Fe}_{2} \mathrm{O}_{3}$ & 0,960 & 0,000 & 0,200 & 0,030 & 0,000 & 0,000 & 0,040 \\
\hline $\mathrm{FeO}$ & 29,650 & 30,850 & 29,900 & 30,360 & 30,420 & 29,870 & 30,390 \\
\hline $\mathrm{MnO}$ & 0,450 & 0,900 & 1,480 & 1,960 & 1,720 & 0,840 & 0,500 \\
\hline $\mathrm{MgO}$ & 5,670 & 4,900 & 4,370 & 3,840 & 4,070 & 4,950 & 5,420 \\
\hline $\mathrm{CaO}$ & 3,260 & 3,250 & 3,810 & 4,100 & 3,570 & 3,400 & 3,290 \\
\hline $\mathrm{Na}_{2} \mathrm{O}$ & 0,000 & 0,000 & 0,000 & 0,000 & 0,000 & 0,000 & 0,000 \\
\hline $\mathrm{K}_{2} \mathrm{O}$ & 0,000 & 0,000 & 0,000 & 0,000 & 0,000 & 0,000 & 0,000 \\
\hline$\sum$ óxidos & 98,470 & 99,100 & 97,880 & 98,770 & 98,130 & 97,480 & 98,720 \\
\hline $\mathrm{Si}$ & 2,962 & 2,989 & 2,972 & 2,987 & 2,999 & 3,002 & 2,983 \\
\hline $\mathrm{Ti}$ & 0,005 & 0,001 & 0,010 & 0,002 & 0,002 & 0,001 & 0,000 \\
\hline $\mathrm{Al}$ & 2,009 & 2,030 & 2,025 & 2,020 & 2,018 & 2,020 & 2,031 \\
\hline $\mathrm{Cr}$ & 0,000 & 0,000 & 0,000 & 0,000 & 0,000 & 0,000 & 0,000 \\
\hline $\mathrm{Fe}^{3+}$ & 0,058 & 0,000 & 0,012 & 0,002 & 0,000 & 0,000 & 0,003 \\
\hline $\mathrm{Fe}^{2+}$ & 1,981 & 2,054 & 2,023 & 2,042 & 2,055 & 2,017 & 2,025 \\
\hline $\mathrm{Mn}$ & 0,030 & 0,060 & 0,101 & 0,133 & 0,117 & 0,057 & 0,034 \\
\hline $\mathrm{Mg}$ & 0,676 & 0,581 & 0,527 & 0,461 & 0,490 & 0,595 & 0,643 \\
\hline $\mathrm{Ca}$ & 0,280 & 0,277 & 0,331 & 0,353 & 0,309 & 0,294 & 0,281 \\
\hline $\mathrm{Na}$ & 0,000 & 0,000 & 0,000 & 0,000 & 0,000 & 0,000 & 0,000 \\
\hline K & 0,000 & 0,000 & 0,000 & 0,000 & 0,000 & 0,000 & 0,000 \\
\hline$\Sigma$ Cátions & 8,000 & 7,994 & 8,000 & 8,000 & 7,990 & 7,987 & 8,000 \\
\hline$\%$ Alm & 66,768 & 69,112 & 67,840 & 68,317 & 69,169 & 68,073 & 67,885 \\
\hline$\% \mathrm{Pyr}$ & 22,784 & 19,549 & 17,673 & 15,423 & 16,493 & 20,081 & 21,555 \\
\hline$\% \mathrm{Sps}$ & 1,011 & 2,019 & 3,387 & 4,450 & 3,938 & 1,924 & 1,140 \\
\hline$\%$ Gros & 6,631 & 9,320 & 10,511 & 11,711 & 10,401 & 9,922 & 9,273 \\
\hline$\%$ And & 2,806 & 0,000 & 0,589 & 0,099 & 0,000 & 0,000 & 0,147 \\
\hline$\%$ Uva & 0,000 & 0,000 & 0,000 & 0,000 & 0,000 & 0,000 & 0,000 \\
\hline$\% \mathrm{Fe} / \mathrm{Fe}+\mathrm{Mg}$ & 74,558 & 77,951 & 79,333 & 81,582 & 80,747 & 77,221 & 75,900 \\
\hline
\end{tabular}

Tabela 5 - Associações minerais presentes nas amostras usadas para termobarometria. A localização das amostras é mostrada na figura 1.

\begin{tabular}{lcccccccc}
\hline Amostras & ME-48 & ME-61 & PO-83 & ME-149 & PO-100 & SG-155 & PO-101 & PO-130 \\
\hline Anfibólio & $\mathrm{X}$ & $\mathrm{X}$ & $\mathrm{X}$ & $\mathrm{X}$ & $\mathrm{X}$ & $\mathrm{X}$ & $\mathrm{X}$ & \\
\hline Biotita & & & & & & & $\mathrm{X}$ & $\mathrm{X}$ \\
\hline Granada & & & & $\mathrm{X}$ & $\mathrm{X}$ & $\mathrm{X}$ & $\mathrm{X}$ \\
\hline Plagioclásio & $\mathrm{X}$ & $\mathrm{X}$ & $\mathrm{X}$ & $\mathrm{X}$ & $\mathrm{X}$ & $\mathrm{X}$ & $\mathrm{X}$ & $\mathrm{X}$ \\
\hline Muscovita & & & & & & & $\mathrm{X}$ & \\
\hline Piroxênio & & & & & & & $\mathrm{X}$ \\
\hline
\end{tabular}


granada + quartzo $+($ ortopiroxênio $)+($ rutilo $)+($ ilmenita), associação indicativa de fácies granulito.

O retrometamorfismo é caracterizado pela presença de minerais que indicam reequilíbrio em condições de fácies anfibolito a xisto verde envolvendo: transformação de granada e anfibólio para biotita e clorita (Fig. 2 - fotomicrograifa $1 \mathrm{C}$ ); formação de ilmenita e titanita a partir do titânio e cálcio liberado nas reações retrometamórficas e de rutilo (Fig. 2 - fotomicrografia 1D); aparecimento de epidoto e mica branca intersticial e sobre o plagioclásio; coroas de albita límpidas na borda do plagioclásio saussuritizado, clorita intersticial e sobre os minerais máficos e a formação de actinolita junto à borda de hornblenda.
A temperatura calculada utilizando-se o geotermômetro plagioclásio + anfibólio variou entre $683^{\circ} \mathrm{C}$ e $880^{\circ} \mathrm{C}$ e a pressão utilizando-se o geobarômetro granada + plagioclásio + anfibólio entre 9,01 kbar e 10,80 kbar, valores compatíveis com o campo de estabilidade da cianita e sillimanita (na fácies anfibolito médio a granulito inferior). Os valores calculados são mostrados na tabela 6 .

A variação composicional dos anfibólios em relação a seus principais componentes é mostrada nos diagramas da figura 4, onde se observa que os anfibólios apresentam composições semelhantes. As amostras possuem baixos valores de $\mathrm{Na}(\mathrm{M} 4)$, teores relativamente baixos de $\mathrm{Al}^{\mathrm{IV}}$ e a proporção $\mathrm{Al}^{\mathrm{IV}}+\mathrm{Fe}^{3}+\mathrm{Ti}$ são

Tabela 6 - Resultados das condições Te P do metamorfismo calculados com o Geotermômetro Hornblenda Plagioclásio e Geobarômetro Granada - Plagioclásio - Hornblenda.

\begin{tabular}{|c|c|c|c|c|c|c|c|}
\hline \multicolumn{8}{|c|}{ Geotermômetro } \\
\hline Amostra & ME-48 & \multicolumn{2}{|c|}{ ME-61 } & ME-149 & PO-83 & PO-100B & SG-155 \\
\hline $8,0 \mathrm{kbar}$ & $758,31-814,75$ & \multicolumn{2}{|c|}{$798,28-813,52$} & $840,59-849,53$ & $822,10-868,85$ & $859,91-880,63$ & $831,12-824,78$ \\
\hline 8,5 kbar & $749,98-806,43$ & \multicolumn{2}{|c|}{$789,95-805,08$} & $832,23-840,80$ & $813,56-859,94$ & $851,11-870,97$ & $821,75-815,58$ \\
\hline 9,0 kbar & $741,66-798,11$ & \multicolumn{2}{|c|}{$781,63-796,64$} & $823,87-832,08$ & $805,02-851,04$ & $842,31-861,31$ & $812,39-806,37$ \\
\hline $9,5 \mathrm{kbar}$ & $733,33-789,79$ & \multicolumn{2}{|c|}{$773,30-788,19$} & $815,50-823,36$ & $796,49-842,13$ & $833,50-851,65$ & $803,03-797,17$ \\
\hline $10,0 \mathrm{kbar}$ & $725,00-781,47$ & \multicolumn{2}{|c|}{$764,97-779,75$} & $807,14-814,63$ & $787,95-833,23$ & $824,70-842,00$ & $793,66-787,97$ \\
\hline $10,5 \mathrm{kbar}$ & $716,67-773,15$ & \multicolumn{2}{|c|}{$756,65-771,30$} & $798,78-805,91$ & $779,42-824,32$ & $815,89-832,34$ & $784,30-778,87$ \\
\hline 11,0 kbar & $708,34-764,83$ & \multicolumn{2}{|c|}{$748,32-762,86$} & $790,42-797,19$ & $770,88-815,41$ & $807,09-822,68$ & $774,93-769,57$ \\
\hline 11,5 kbar & $700,02-756,52$ & \multicolumn{2}{|c|}{$740,00-754,42$} & $782,05-788,46$ & $762,34-806,51$ & $798,28-813,02$ & $765,57-760,37$ \\
\hline $12,0 \mathrm{kbar}$ & $691,69-748,20$ & \multicolumn{2}{|c|}{$731,67-745,97$} & $773,69-779,74$ & $753,81-797,60$ & $789,48-803,36$ & $756,20-751,17$ \\
\hline $12,5 \mathrm{kbar}$ & $683,36-739,88$ & \multicolumn{2}{|c|}{$723,35-737,53$} & $765,33-771,02$ & $745,25-788,70$ & $780,68-793,70$ & $746,84-741,96$ \\
\hline \multicolumn{8}{|c|}{ Geobarômetro (amostra PO-100) } \\
\hline Temperatura & P kbar & Temperatura & P kbar & Temperatura & P kbar & Temperatura & P kbar \\
\hline $600^{\circ} \mathrm{C}$ & $9,0-10,71$ & $700^{\circ} \mathrm{C}$ & $9,91-10,58$ & $800^{\circ} \mathrm{C}$ & $10,45-10,84$ & $900^{\circ} \mathrm{C}$ & $10,33-11,75$ \\
\hline $650^{\circ} \mathrm{C}$ & $9,45-10,64$ & $750^{\circ} \mathrm{C}$ & $10,37-10,52$ & $850^{\circ} \mathrm{C}$ & $10,39-11,29$ & $950^{\circ} \mathrm{C}$ & $10,27-12,21$ \\
\hline
\end{tabular}
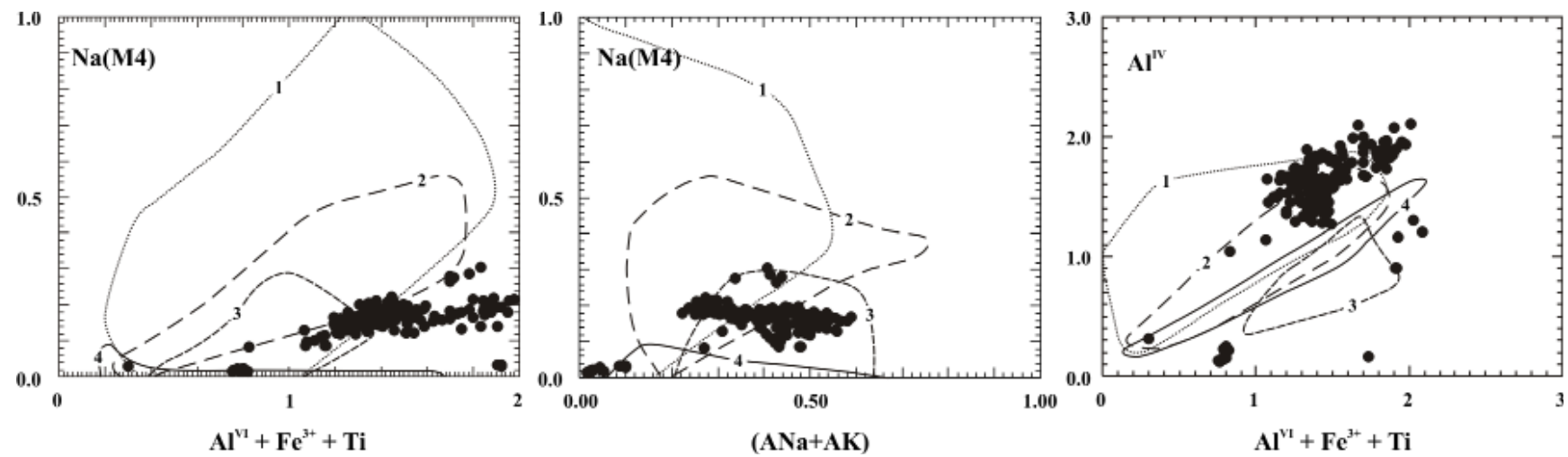

Figura 4 - Diagrama de Na(M4) $x A l^{V I}+\mathrm{Fe}^{3+}+\mathrm{Ti}$, Na(M4) $x(A N a+A K), A l^{V I} \times A l^{V I}+\mathrm{Fe}^{3+}+\mathrm{Ti}$, dos anfibólios analisados (modificados de Spear 1995). 1 = campo composicional de anfibólios dos terrenos de alta pressão (Cinturão Sambagawa e Franciscano), 2 e 3 = campo composicional de anfibólios dos terrenos de média pressão (Dalradian e Haast River), 4 = campo composicional de anfibólios dos terrenos de baixa pressão (Abukuma). 
semelhantes a composições relacionadas a ambientes de média pressão (ex: Dalradian na Escócia e Haast River na Nova Zelândia).

Dados termobarométricos obtidos para gnaisses da região, calculados utilizando o programa THERMOCAL, para associações anfibólio cálcico + biotita + plagioclásio + granada e biotita + plagioclásio + granada + muscovita, variaram entre $580 \pm 33^{\circ} \mathrm{C}-628$ $\pm 17^{\circ} \mathrm{C}$ e $7,99 \pm 1,18 \mathrm{kbar}-8,66 \pm 0,77 \mathrm{kbar}$, valores compatíveis com a fácies anfibolito (anfibolito médio) no campo de estabilidade da cianita e estaurolita. Valores semelhantes de $T$ e $P$ foram calculados utilizando o programa THERMOCALC para a associação plagioclásio + granada + anfibólio cálcico (rocha metamáfica, amostra PO-100), cujos valores foram de $578 \pm$ $35^{\circ} \mathrm{C}$ e de $8,49 \pm 1,27$ bar.

As temperaturas calculadas pelo par plagioclásio + anfibólio estão altas em relação às associações minerais presentes nas rochas encaixantes (fácies anfibolito médio, zona da cianita - estaurolita). As temperaturas são compatíveis com a fácies anfibolito médio a granulito inferior (de média pressão). Entretanto, cabe ressaltar que excetuando a amostra com a paragênese plagioclásio + clinopiroxênio + granada + quartzo + (ortopiroxênio) + (rutilo) + (ilmenita), que foi encontrada em apenas um afloramento (SG-155), não existe evidência petrográfica, textural e mineralógica indicando que a região atingiu a transição entre a fácies anfibolito e granulito.

A presença de plagioclásios com composições distintas coexistindo (amostras PO-83 e PO-100), um com composição mais ácida (oligoclásio/andesina) e outro mais básico (labradorita/bytownita), sugere que a rocha não atingiu o equilíbrio químico e que parte das composições observadas são, na verdade, composições próximas às composições iniciais de formação. Desta forma é provável que as temperaturas muito altas $\left(>775^{\circ} \mathrm{C}\right)$, indicativas de condições de transição da fácies anfibolito para granulito, não representem as condições metamórficas alcançadas e, sim, as condições químicas em desequilíbrio. Em temperaturas de aproximadamente $775^{\circ} \mathrm{C}$, a hornblenda, através de reações contínuas, origina clinopiroxênio + plagioclásio, marcando a transição da fácies anfibolito para granulito (Spear 1981). O aparecimento de ortopiroxênio constituindo uma associação com clinopiroxênio + plagioclásio \pm (hornblenda) \pm (granada) \pm (biotita) \pm (quartzo) \pm (rutilo) \pm (ilmenita) marcaria a fácies granulito típica em rochas metabásicas (Spear 1995). Com exceção da amostra (SG-155), a ausência de minerais e associações minerais compatíveis com as temperaturas muito altas (como por exemplo, presença de minerais hidratados e ausência de ortopiroxênio, de sillimanita, de migmatização evidente etc.) indicam que essas condições (fácies anfibolito superior/ granulito) não foram alcançadas regionalmente. Outra possibilidade é que o auge metamórfico tenha ocorrido em condições de pressão e temperaturas mais elevadas, mas não foram encontradas, até o momento, evidências mineralógicas ou petrográficas indicando que condições de transição de fácies anfibolito para granulito tenham sido atingidas regionalmente (fácies anfibolito superior a transição com a fácies eclogito/granulito).

As texturas de desmisturação de cummingtonita em cristais de hornblenda, observadas em algumas seções delgadas, também evidenciam que temperaturas da ordem de 700 a $750^{\circ} \mathrm{C}$ foram atingidas, com base em trabalhos experimentais de Robinson et al. (1982) e Oba \& Nicholls (1986).

Navarro \& Zanardo (2005) apresentam estimativas das condições de $P-T$ do metamorfismo utilizando o conteúdo total de Ti em anfibólios (geotermômetro) e de $\mathrm{Al}$ em hornblenda (geobarômetro) (programa ESCHER - Otten 1984). O geotermômetro indicou temperaturas que variam de $550^{\circ} \mathrm{C}$ a $700^{\circ} \mathrm{C}$ (com predomínio de temperaturas na ordem de $570^{\circ} \mathrm{C}$ a $630^{\circ} \mathrm{C}$ ) e as pressões calculadas pelo geobarômetro variaram entre $3 \mathrm{kbar}$ e $11 \mathrm{kbar}$ (com predomínio de pressões por volta de 5 a $9 \mathrm{kbar}$ ). Os dados mostram que as rochas foram submetidas a condições de $P$ e $T$ na fácies anfibolito médio, no campo de estabilidade da cianita e são sugestivas de caminhamento metamórfico do tipo horário. A ampla variação nos resultados foi interpretada como resultado de efeitos de retrometamorfismo ou reequilíbrio composicional pós-auge metamórfico, ou então, que o auge metamórfico ocorre em condições mais elevadas de $P$ e $T$ (Navarro \& Zanardo 2005).

De forma sistemática, as rochas anfibolíticas da região mostram temperaturas e pressão superiores às registradas nas rochas encaixantes, mesmo as evidências geológicas indicando que foram submetidas ao mesmo evento tectono-metamórfico.

Neste contexto, é bem provável que as condições metamórficas nas rochas metamáficas/metabásicas representem o auge metamórfico regional, denominado informalmente de (M1) de fácies anfibolito médio a superior (caracterizado pela associação plagioclásio + anfibólio e granada + plagioclásio + anfibólio), e que as associações minerais registradas nas rochas encaixantes representem um equilíbrio retrometamórfico (M2), também em fácies anfibolito, porém em condições mais brandas (ambos relacionados a um mesmo evento deformacional progressivo de caráter regional). Esta diferença pode ser explicada com base na deformação (xistificação) bem mais acentuada nas rochas encaixantes, em razão de diferenças reológicas, fato que teria destruído o equilíbrio de maior grau nas encaixantes e apenas parcialmente nas rochas anfibolíticas, como observado na petrografia.

CONCLUSÕES As rochas da região apresentam paragêneses minerais e/ou associações minerais relacionadas ao auge metamórfico típicas da fácies anfibolito. Os cálculos termobarométricos mostram que as condições de $P$ e $T$ para as associações anfibólio cálcico + plagioclásio e plagioclásio + granada + anfibólio cálcico variaram entre $683^{\circ} \mathrm{C}$ e $880^{\circ} \mathrm{C}$, e entre $9,01 \mathrm{kbar}$ e 10,80 kbar. Estes valores indicam uma variação do metamorfismo da fácies anfibolito médio a granulito inferior. Entretanto os cálculos para as associações minerais anfibólio cálcico + biotita + granada + plagioclásio 
e biotita + granada + plagioclásio + muscovita presentes nas rochas encaixantes são compatíveis com a fácies anfibolito médio. Da mesma forma, dados termobarométricos do Grupo Araxá, que ocorrem na região, também são da fácies anfibolito, zona da estaurolita e cianita, com condições de pico metamórfico entre $610^{\circ} \mathrm{C}$ e 9,5 kbar (Navarro et al. 2009), semelhante às condições metamórficas das rochas gnáissicas da região. A química mineral dos anfibólios analisados, presentes nas rochas metamáficas/metabásicas, também indicam que as condições metamórficas alcançadas são da fácies anfibolito médio a superior.

Como não existem evidências (texturais, petrográficas, minerais ou associações minerais) nas rochas da região e mesmo nas unidades geológicas adjacentes (Grupo Araxá e Sequência Metavulcano-sedimentar Anicuns-Itaberaí) de grau metamórfico elevado, com exceção de uma amostra (SG-155) que mostra textura e paragênese de fácies granulito, as temperaturas mais elevadas obtidas no cálculo termobarométrico (que indicam fácies anfibolito superior/granulito) representam condições químicas em desequilíbrio, não representando as condições metamórficas atingidas regionalmente. Neste sentido, a amostra SG-155, que apresenta uma associação anômala (fácies granulito) em relação às rochas presentes na região, não está inserida no contexto metamórfico regional e deve corresponder a um enclave tectônico de outra unidade geológica.

Os dados termobarométricos obtidos neste trabalho indicam que o ápice metamórfico (M1), está registrado somente nas rochas metamáficas/metabásicas, é da fácies anfibolito médio a superior e atingiu temperaturas pouco superiores à $700^{\circ} \mathrm{C}$ (não ultrapassando $775^{\circ} \mathrm{C}$ ), em condições de média pressão ( $10 \mathrm{kbar})$, no campo de estabilidade da cianita. $\mathrm{O}$ registro de $T$ e $P$ observado nas rochas gnáissicas em condições mais brandas ( $T$ entre $580 \pm 33^{\circ} \mathrm{C}-628 \pm 17^{\circ} \mathrm{C}$ e P entre $7,99 \pm 1,18$ $8,66 \pm 0,77 \mathrm{kbar}$ ) representa registro de um reequilíbrio tectono-metamórfico (M2) de caráter regional (Fig. 5).

As associações minerais e os cálculos termobarométricos mostram que, na região, o ápice metamórfico é da fácies anfibolito médio a superior e que esta associação foi recalibrada em grau variado, parcial a total, de acordo com as propriedades reológicas dos protólitos, para condições mais brandas da fácies anfibolito e/ou xisto verde, catalisadas por deformação e/ou percolação de fluidos. As condições de maior grau metamórfico ficaram registradas apenas nas rochas ricas em anfibólio. Nas rochas encaixantes, mais suscetíveis à deformação, as condições de maior grau

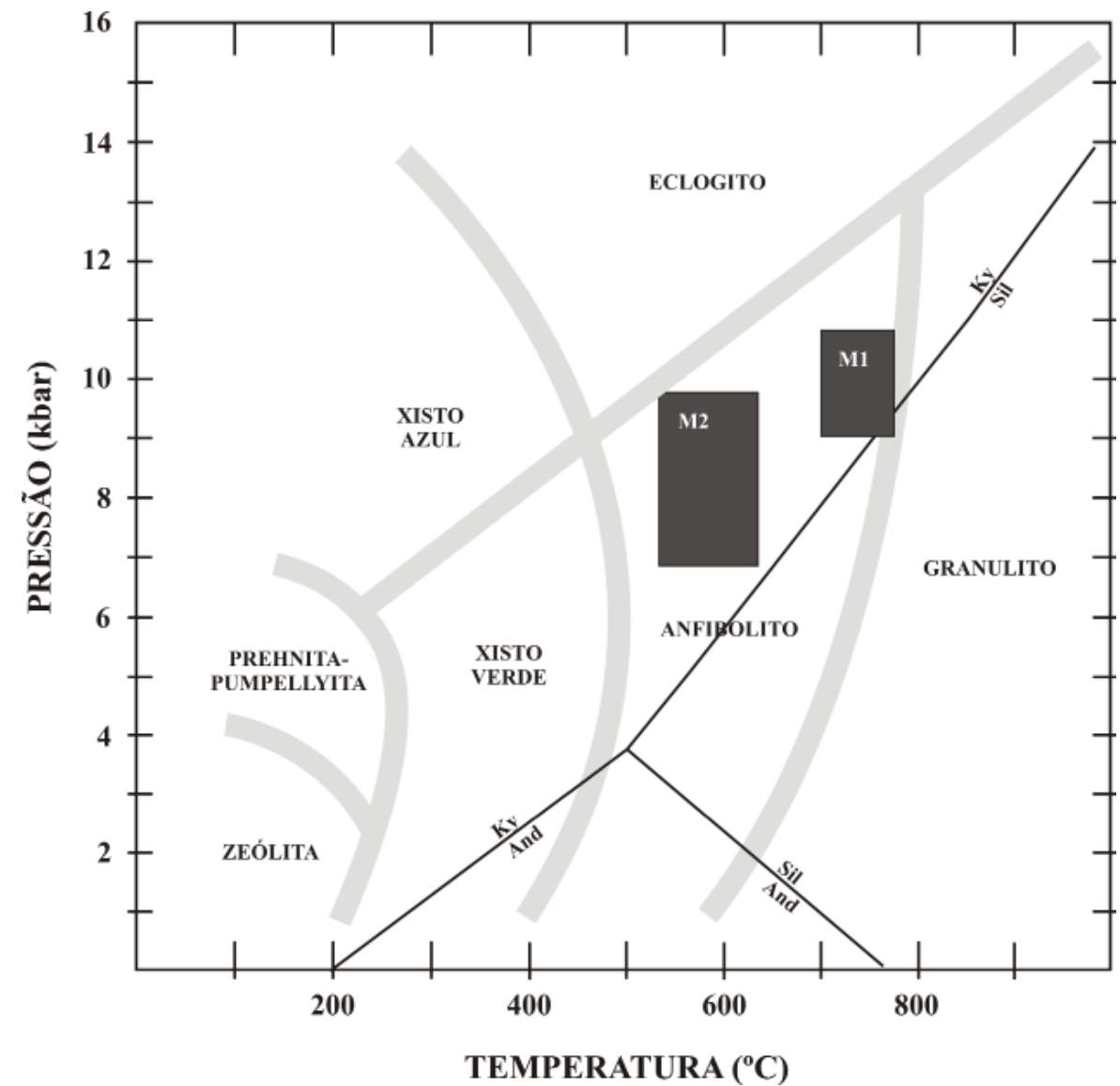

Figura 5 - Diagrama P - T, mostrando os intervalos das condições do metamorfismo M1 e M2 para as rochas do metabásicas/metamáficas e gnáissicas da região de Pontalina. Os campos da fácies metamórficas compilados de Spear (1995). 
metamórfico foram reequilibradas de forma mais efetiva para condições de menores pressões e temperaturas, apagando totalmente evidência do auge metamórfico. Após cessar a deformação dúctil a dúctil-rúptil as transformações retrometamórficas continuam a ocorrer, aspecto caracterizado pela presença de clorita, muscovita/sericita e epidoto sem deformação e com disposição caótica. Os aspectos texturais, metamórficos e termobarométricos evidenciam um caminhamento $P-T$ horário para a região.

Agradecimentos À FAPESP (Processos $\mathrm{n}^{\circ}$ 2001/10034-2, 2005/59203-1 e 08/50723-0) e CNPq (Processos n ${ }^{\circ}$ 140418/2002-4 e 303267/2002-0).

\section{Referências}

Blundy J.D. \& Holland T.J.B. 1990. Calcic amphibole equilibria and a new amphibole-plagioclase geothermometer. Contributions to Mineralogy and Petrology, 104:208-224.

Holland T. \& Blundy J. 1994. Non-ideal interactions in calcic amphiboles and their bearing on amphiboleplagioclase thermometry. Contributions to Mineralogy and Petrology, 116:433-447.

Kohn M.J. \& Spear F.S. 1989. Empirical calibration of geobarometers for the assemblage garnet+hornblende+ plagioclase+quartz. American Mineralogist, 74:77-84.

Kohn M.J. \& Spear F.S. 1990. Two new geobarometers for garnet amphibolites, with applications to southeastern Vermont. American Mineralogist, 75:89-96.

Leake B.E., Woolley A.R., Arps C.E.S., Birch W.D., Gilbert M.C., Grice J.D., Hawthorne F.C., Kato A., Kisch H.J., Krivovichev V.G., Linthout K., Laird Jo, Mandarino J.A., Maresch W.V., Nickel E.H., Rock N.M.S., Schumacher J.C., Smith D.C., Stephenson N.C.N., Ungaretti L., Whittaker E.J.W., Youzhi G. 1997. Nomenclature of amphiboles: Report of the Subcommittee on Amphiboles of the International Mineralogical Association, Commission on New Minerals and Mineral Names. American Mineralogist, 82:1019-1037.

Morimoto N. 1988. Nomenclature of pyroxenes. Canadian Mineralogist, 27:143-156.

Navarro G.R.B. \& Zanardo A. 2005. Química mineral de anfibólios e estimativas de Pressão e Temperatura de rochas metamáficas da região de Pontalina - GO. In: SBG, Simpósio de Geologia do Centro-Oeste, 9, Resumos, p. 173-176.

Navarro G.R.B. \& Zanardo A. 2006. Dados geoquímicos e isotópicos de rochas metamáficas da região de Pontalina - GO. Revista de Geologia, 19(2):207-214.

Navarro G.R.B. \& Zanardo A. 2007a. Geoquímica de Gnaisses do Arco Magmático de Goiás na região sul do estado de Goiás. Geologia USP. Série Científica, 7(1):19-28.

Navarro G.R.B. \& Zanardo A. 2007b. Características geoquímicas de gnaisses da Unidade Metassedimentar, porção sul do Arco Magmático de Goiás, na região de Pontalina. In: SBGq, Congresso Brasileiro de Geoquímica, 11, Resumos, 4 p. CD-ROM - 539.
Navarro G.R.B., Zanardo A., Simões L.S.A. 2007. Rochas metamáficas associadas ao Arco Magmático de Goiás na região de Pontalina - GO. Revista Brasileira de Geociências, 37(4 - suplemento especial):18-27.

Navarro G.R.B., Moraes R., Zanardo A., Simões L.S.A. 2009. Trajetórias P-T e condições do metamorfismo usadas como ferramenta para compartimentação tectônica da Faixa Brasília em Goiás. Revista Brasileira de Geociências. 39(3):544-559.

Oba T. \& Nicholls I.A. 1986. Experimental study of cummingtonita and $\mathrm{Ca}-\mathrm{Na}$ amphibole relations in the system Cum-Act-Pl-Qz-H O. American Mineralogist, 71:1354-1365.

Otten M.T. 1984. The origin of brown hornblende in the Artfllet gabbro and dolerites. Contributions to Mineralogy and Petrology, 86:189-199.

Powell R. \& Holland T. 1994. Optimal geothermometry and geobarometry. American Mineralogist, 79:120-144.

Richard, L. R. 1995. MinPet - Mineralogical and Petrological Data Processing System version 2.02. MinPet Geological Software, Québec, Canadá, 1995.

Robinson P., Spear F.S., Schumacher J.C., Laird J., Klein C., Evans B.W., Doolan B.L. 1982. Phase relations of metamorphic amphiboles: Natural occurrence and theory. Reviews in Mineralogy and Geochemistry, 9B(1):1-211.

Spear F.S. 1981. An experimental study of hornblende stability and compositional variability in amphibole. American Journal of Science, 281:697-734.

Spear F. S. 1995. Metamorphic Phase Equilibria and Pressure-Temperature-Time Paths. Mineralogical Society of America (ed.). Washington: Mineralogical Society of America - Monograph, 799 p.

Soto J.I. \& Soto V.M. 1993. Program for thermobarometry and activity calculations with mafic and ultramafic assemblages version 2.0. Department of Geodynamic, University Granada, Spain, 1993.

Manuscrito ID 14651 Submetido em 14 de setembro de 2010 Aceito em 02 de dezembro de 2010 